(c) 2015, Elsevier. Licensed under the Creative Commons Attribution-NonCommercial-NoDerivatives 4.0 International http://creativecommons.org/licenses/by-nc-nd/4.0/

\title{
Strategic Supplier Performance Evaluation: A Case-based Action Research of a UK Manufacturing Organisation
}

\author{
Prasanta Kumar Dey \\ Operations \& Information Management Group, Aston Business School \\ Aston University, Birmingham, B4 7ET, UK.
}

Arijit Bhattacharya

Brunel Business School, Brunel University, Kingston Lane

Uxbridge, Middlesex, UB8 3PH, UK.

\author{
William Ho \\ (Corresponding Author) \\ Department of Management and Marketing \\ The University of Melbourne \\ 198 Berkeley Street, Carlton, \\ Victoria 3010, Australia. \\ Telephone: +61-3-90357560 \\ Email: william.ho@unimelb.edu.au
}

\begin{abstract}
The main aim of this research is to demonstrate strategic supplier performance evaluation of a UK-based manufacturing organisation using an integrated analytical framework. Developing long term relationship with strategic suppliers is common in today's industry. However, monitoring suppliers' performance all through the contractual period is important in order to ensure overall supply chain performance. Therefore, client organisations need to measure suppliers' performance dynamically and inform them on improvement measures. Although there are many studies introducing innovative supplier performance evaluation frameworks and empirical researches on identifying criteria for supplier evaluation, little has been reported on detailed application of strategic supplier performance evaluation and its implication on overall performance of organisation. Additionally, majority of the prior studies emphasise on lagging factors (quality, delivery schedule and value / cost) for supplier selection and evaluation. This research proposes both leading (organisational practices, risk management, environmental and social practices) and lagging factors for supplier evaluation and demonstrates a systematic method for identifying those factors with the involvement of relevant stakeholders and process mapping. The contribution of this article is a real-life casebased action research utilizing an integrated analytical model that combines Quality Function Deployment and the Analytic Hierarchy Process method for suppliers' performance evaluation. The effectiveness of the method has been demonstrated through number of validations (e.g. focus group, business results, and statistical analysis). Additionally, the study reveals that enhanced supplier performance results positive impact on operational and business performance of client organisation.
\end{abstract}

Keywords: Strategic supplier performance evaluation; Risk; Environmental considerations; Economical factors; Quality function deployment; Analytic hierarchy process. 


\section{Introduction}

Today's manufacturing procurement focuses on building long term relationships with upstream suppliers and downstream customers to enhance supply chain performance. Performance evaluation of suppliers is regarded as an essential element of today's production planning and control (Chan et al. 2003). It not only integrates supply chain stakeholders but also enhances supply chain performance through capitalising potential opportunities (Holmberg 2000; Chan et al. 2003). Organisations require a structured flexible framework (constructs and methods) to facilitate in auditing suppliers' performance (Medori and Steeple 2000) that in turn helps improve entire supply chain performance. Further, it has been reported that although there are frameworks for evaluating suppliers' performance about $60 \%$ of enterprises are unhappy regarding their "ability to consistently measure and manage supplier performance" (Minahan and Vigoroso 2002). Therefore, an effective supplier performance measurement framework is required, which is easily adoptable, efficient, reliable, flexible, and compatible to other organisational systems. Further, an effective supplier performance measurement method provides feedback to suppliers to improve their performance.

Procurement cost comprises of $60 \%-80 \%$ of production cost for many manufacturing organisations. Suppliers not only contribute in product innovation, but also help achieve highly effective production processes. Therefore, enhancement of supplier performance helps achieve overall organisational excellence. Although supplier evaluation eventually facilitates to improve supplier performance through identifying improvement measures, such measures are complex and cumbersome to implement (Estampe et al. 2013). These measures are critical to success (Fawcett and Cooper 1998). The suppliers' performances are well related to manufacturing performance enabling the firm to meet its manufacturing objectives. Therefore, firms' communication channels with suppliers are required to be improved (Galt and Dale 1991; Vonderembse and Tracey 1999).

There are abundant studies on supplier selection and evaluation. On one hand there are studies on methods for supplier selection and evaluation, and on other hand there are researches on constructs for supplier performance measurement. Number of studies demonstrates innovative frameworks for suppler selection and evaluation using operations research tools and techniques such as the analytic hierarchy process, the analytic network process, fuzzy theory, data envelopment analysis, and multi objective decision analysis. There are also hybrid methods, where two or more techniques are combined together to develop innovative heuristics for supplier performance evaluation.

Although there are studies on innovative frameworks for supplier selection and evaluation and their applications in industry, real life demonstration of supplier performance measurement and its impact on overall supply chain performance is scant. Moreover, systematic identification of most appropriate criteria for supplier evaluation with the consideration of both leading (proactive) and lagging (reactive) factors is also rare. The objective of this case-based action research is to identify appropriate criteria for supplier evaluation, develop an analytical framework for performance measurement, measure supplier 
performance of a UK-based manufacturing organisation and suggest improvement measures, and reveal the impact of supplier performance on operations and overall business performance in the downstream client organisations.

The paper is organised as follows. Section 2 articulates the existing methods for supplier performance assessment and factors / criteria / constructs for suppliers' performance evaluation through an exhaustive literature review. Section 3 explains the methodology that has been used to measure the supplier performance. Section 4 describes the case-based action research for the supplier performance evaluation within a UK-based carpet manufacturing organisation. Section 5 elucidates the contributions through discussion on both theoretical and practical implications of this research. Section 6 concludes the article indicating further scope of research.

\section{Literature Review}

There have been number of studies on supplier selection and evaluation covering both wide range of constructs and methods. Recently, there are number of review articles (e.g. Ho et al. 2010, Chen 2011, Chai et al. 2013) revealing both constructs and methods for supplier selection. Prior studies reveal that analytic supplier selection processes result in better decision outcomes (Kaufmann et al. 2012). More recently hybrid methods have become more popular in research and industry (Chai et al. 2013).

The following paragraphs describe the literatures on methods and constructs for supplier performance evaluation along with rationale for selecting the integrated analytical approach for this study.

\subsection{Supplier evaluation methods}

Multiple Attribute Decision-Making (MADM) techniques have been extensively used for supplier selection and evaluation (Chai et al. 2013). Ho et al. (2010) report that the analytic hierarchy process (AHP) is the most popular method for supplier selection. Levary (2008) and Lin et al. (2010) use the AHP and the Analytic Network Process (ANP) respectively. Other MADM techniques like Elimination and Choice Expressing Reality (ELECTRE), Preference Ranking Organisation Method for Enrichment Analysis (PROMETHEE), Techniques for Order Performance by Similarity to Ideal Solution (TOPSIS) have been demonstrated by Sevkli (2010), Chen et al. (2011b) and Saen (2010) respectively for supplier selection and evaluation. Wu and Blackhurst (2009) use Data Envelopment Analysis (DEA), Lin et al. (2011) adopt linear programming, Hsu et al. (2010) apply non-linear programming, Yu et al. (2012) use multi-objective programming, Kull and Talluri (2008) utilise goal programming, and Li and Zabinsky (2011) apply stochastic programming. Researchers also apply artificial intelligence techniques such as genetic algorithm (Guneri et al. 2011), grey system theory (Tseng 2011), neural network (Lee and Ouyang 2009), Bayesian networks (Ferreira and Borenstein 2012), decision tree (Guo et al. 2009), case based reasoning (Faez et al. 2009), and ant colony algorithm (Tsai et al. 2010). 
Additionally, number of hybrid methods has been proposed. The AHP and ANP have been combined extensively with linear programming and goal programming for supplier selection and evaluation (e.g. Kull and Talluri 2008; Demirtas and Üstün, 2008; Demirtas and Üstün, 2009). Researchers have also combined DEA with other MADM techniques such as the AHP, ANP, TOPSIS etc. (e.g. Azadeh and Alem 2010; Zeydan et al. 2011; Kuo and Lin 2012, Zhang et al. 2012). There are studies (e.g. Wang et al. 2009; Lin 2012) that combine MADM techniques and mathematical programming techniques for supplier selection. Fuzzy theory has been used extensively by the researchers in combination with other methods such as the AHP, ANP, TOPSIS ELECTRE, PROMETHEE, DEA, linear programming, goal programming, multiple objective programming etc. for supplier selection (e.g. Montazer et al. 2009; Wang et al. 2009; Azadeh and Alem 2010; Amid et al. 2011; Chen et al. 2011a; Vinodh et al. 2011; Bhattacharya et al. 2014; Jadidi et al. 2014).

Quality Function Deployment (QFD), a customer focused approach, has been used by Ansari and Modarress (1994) for supplier selection. Rich (1995) shows the application of QFD for evaluating the potential suppliers in an automotive industry. Bevilacqua et al. (2006) combine fuzzy QFD in order to model stakeholder requirements in supplier evaluation. Bhattacharya et al. (2010) use an integrated QFD-AHP method to determine importance of stakeholder requirements in supplier selection. More recently Ho et al. (2011) and Scott et al. (2013) also apply a combined QFD-AHP approach for strategic supplier selection using three houses of quality.

As revealed in prior researches, every method has its pros and cons. The selection of specific method for supplier evaluation depends on many factors such as characteristics of supplier evaluation constructs, implications of supplier evaluation decision on overall organisational performance, user friendliness, flexibility, and both capital cost and operating costs of the model. In fact, there is no best method. Therefore, there is significance of demonstrating real life case study of supplier evaluation in order to depict the process involved, perceptions of the stakeholders, constructs being considered, comfortableness of using a specific method, and the impact of supplier evaluation on overall organisational performance.

\subsection{Supplier performance evaluation criteria}

Prior studies use traditional supplier selection criteria - quality, delivery schedule and past performance (e.g. Lehmann and O'Shaughnessy 1982). Wilson (1994) uses flexibility and services of suppliers along with delivery schedule. Swift (1995) introduces number of indicators (product, dependent, experience, price and acquired) in order to decide single or multiple supplier. Goffin et al. (1997) reveal that earlier studies consider price, quality and speed of delivery for supplier selection and current studies focus on suppliers' technological capacity, financing capability, after-sales service and strategic considerations. Narasimhan et al. (2001) put forward to major evaluation indicators - supplier capability and supplier performance. Quayle (2002) suggests number of criteria - price, quality, time to market immediacy, product credibility, service reliability, support capability, research and development power, purchase speciality, value analysis, value engineering and e-commerce. 
Schmitz and Platts (2004) list supplier performance indicators as suppliers' strategic planning, information management, relationship with other suppliers, positiveness, coordination capability, priority decision capability, and learning competence. Both Chan et al. (2008) and Şen et al. (2008) propose qualitative and quantitative factors for supplier evaluation. Kuo and Lin (2012) use four dimensions (organisation structure and manufacturing capability, supplier's implementation capability, quality system, and environmental issues) for supplier evaluation and selection. The prior studies clearly indicate that there is lack of uniformity of criteria for supplier evaluation. This study argues that evaluation criteria have strategic intent and need to be related to business processes and stakeholders' requirements. Accordingly, this research demonstrates a robust approach to identify the most appropriate criteria for supplier performance evaluation through process mapping, identifying stakeholders and their importance in supplier evaluation, and stakeholders' requirements and the importance of their requirements. It systematically proposes both leading (proactive) and lagging (reactive) factors for supplier evaluation.

This case-based action research develops an integrated QFD-AHP model that has been adapted from Ho et al. (2011) in order to accommodate strategic intent of the organisation in supplier performance evaluation. Ho et al. (2011) use the AHP (pair-wise comparison) to derive the importance of stakeholders, their requirements, criteria / sub-criteria, and priorities of supplier with respect to each sub-criterion. While this is theoretically correct and desirable, has serious shortcoming in practical application because of large number of stakeholders' requirements, criteria and sub-criteria and suppliers. The AHP analysis not only results inconsistency if pair-wise comparison matrix becomes large, there is a chance of rank reversal. Moreover, practitioners need more simplistic approach for analysis. In order to avoid these difficulties, the proposed framework has adopted developing relationship matrix in each stage of QFD analysis instead of pair-wise comparison. The proposed model deploys the AHP for determining importance of stakeholders and determining priority of the suppliers against each bottom level criterion. While QFD allows identifying supplier evaluation criteria / sub-criteria through stakeholders' involvement, the AHP determines their importance through relative ranking and normalising across the houses of quality. The outcome of the analysis is the ranking and relative performance of each participating suppliers. This helps identify improvement measures for each supplier through gap analysis. Additionally, this facilitates cross learning through exposure to the best practices of participating organisations. The remainder of the article demonstrates the proposed supplier performance evaluation using the integrated QFD-AHP model.

The contributions of this research are four folds. First, it extends Ho et al.'s (2011) strategic sourcing method to strategic supplier performance measurement model through introduction of co-relation matrix approach between voice of customers (What) and voice of technical person (How) instead of pair-wise comparison among stakeholders' requirements, the criteria and sub-criteria. Second, it demonstrates a method for identifying the most appropriate criteria and sub-criteria for supplier performance evaluation through identifying stakeholders, their requirements, and mapping business processes vis-à-vis identifying process parameters. Third, it studies the causal relationship of among supplier performance, operational 
performance and business performance using combined statistical and qualitative approach. Finally, it demonstrates a case of UK manufacturing to show the pathway for furthering recent manufacturing boom in the UK.

\section{Methodology}

This action research adopts a case study approach within a UK-based carpet manufacturing organisation using number of focus groups. This study applies a ten step methodology to evaluate supplier performance using the integrated QFD-AHP model. First, a stakeholder group was formed for supplier performance measurement through supplier classification. Second, the stakeholders' importance in decision-making was derived using pair-wise comparison in the AHP framework. Third, each stakeholder's requirements were identified through focus group with the involvement of the representatives of each stakeholder. Fourth, the first house of quality was formed through developing relationship between stakeholder ('what') and their requirements ('how'). The relative importance of the each stakeholder's requirements was derived using $0-9$ scale ( 0 being no relationship and 9 being strongest relationship) followed by normalisation. The overall importance of the stakeholders' requirements was derived through multiplying stakeholder's importance with the relative importance of each requirement and adding across column. Fifth, criteria and sub-criteria for supplier performance evaluation were then identified with the consideration of the concerned organisation's tactical level business processes using focus group. This results in hierarchical structure of criteria and sub-criteria. Sixth, the second house of quality was then formed through developing relationship between the stakeholders' requirements ('what') and the subcriteria ('how') of the hierarchical framework. The relationship between stakeholders' requirements and sub-criteria was derived using $0-9$ scale ( 0 being no relationship and 9 being strongest relationship). Relative importance was then derived using normalisation. The overall importance of the sub-criteria was then derived by multiplying the importance of each stakeholder's requirement with corresponding importance on sub-criteria and adding across the column. Seventh, the concerned suppliers' performance information was gathered against each sub-criterion for supplier performance evaluation. This information was made available to the focus group in order to perform pair-wise comparison of supplier performance with respect to each construct. Eighth, the third house of quality was formed using the pair-wise comparison data of supplier performance against each sub-criterion. The overall performance of supplier was derived by multiplying the importance of each sub-criterion with corresponding supplier performance and adding across the column. Ninth, the information in each house of quality was then thoroughly reviewed in order to reveal improvement measures for enhancing performance of each supplier. A detailed improvement project plan was formulated. Tenth, the proposed measures were implemented and benefits and lessons learned were revealed.

Figure 1 depicts the integrated QFD-AHP model for supplier performance evaluation. The detailed description on the use of pair-wise comparison matrix of the AHP and its application (Saaty 1990, 1994) and the QFD technique are available elsewhere (Bhattacharya

et al. 2005; Chen 2009). The QFD framework has been adapted from Ho et al. (2011) with integration of the scoring method. 
$<$ INSERT Figure 1 ABOUT HERE $>$

\section{Case-based Action Research of a UK-based Carpet Manufacturing Organisation}

The carpet manufacturing company has been a family-owned business in the UK since 1783. Its current turnover is slightly over $£ 100$ Millions. It has manufacturing facilities in two places in the West Midlands, in Pune (India) and in Portugal, and is currently expanding its manufacturing in China. The company exports its products to most of the major markets across the world. Three-quarters of its products are custom made and the rest are sold through dealers in the UK. It is actively working to improve its environmental performance and reduce its impact on the environment through implementing a robust environmental policy, and is accredited to ISO14001:2004. The company takes environmental and social responsibilities very seriously and is committed to the long-term aims of sustainable development in all its business activities. It feels green supply chain management is central to the business, as the product is intrinsically 'green': carpets come from renewable resources - wool from grass-fed sheep - and have extended lifecycles, and manufacturing plants continually strive to reduce their environmental footprint by training environmentally aware employees in sustainable communities. It also extends the green supply chain theme by recycling process waste and finished carpet at the end of its life. In recognition of its sustainability credentials, this company contributes positively to the Leadership in Energy and Environmental Design building certification criteria. It also meets the stringent standards of the Carpet and Rug Institute Green Label Plus programme, contributing to a healthy indoor environment.

The carpet manufacturing firm under investigation has developed strategic partnership with wool and jute manufacturers. They receive value for money for these materials because of strategic alliance with suppliers. Products quality and delivery performance of their strategic suppliers are reasonably good. Order-wise inspection is carried out on receipt of the materials. On average, two nonconformities are observed within 500 occasions in two months. There is no dynamic supplier performance measurement framework in place. As the company deals with high-end customised products, high level of reliability from suppliers is critical to their business. It has been noticed that the company's strategic suppliers have moderate overall reliability.

The following paragraphs demonstrate the application of the combined QFD-AHP approach to supplier performance evaluation within the UK case study organisation.

\section{Step 1: Identifying stakeholders}

The procurement department of the concerned organisation classifies their procured materials / products into categories as per products complexity and commercial uncertainty. The stakeholder for the materials / products with low complexity and low commercial uncertainty are mainly procurement department dominant. Products / materials with high complexity and low commercial uncertainty are engineering department dominant. Products / 
materials with low complexity and high commercial uncertainty are finance department dominant. Products / materials with both high complexity and high commercial uncertainty need the involvement of cross functional group. All the strategic materials / products fall under these categories. This case-based action research considers evaluating wool, chemical and dyes, yarns manufacturers' performance. They are the strategic suppliers for the concerned carpet manufacturing organisation. A multidisciplinary team was involved representing finance, procurement, production, quality, technical, marketing departments and top management for the entire study.

\section{Step 2: Deriving importance of stakeholders through pair-wise comparison in the AHP framework}

The representatives of each department took part in a focus group to derive relative importance of the stakeholders through pair-wise comparison in the AHP framework. Table 1 shows the pair-wise comparison using Saaty's scale (Saaty 1977). The group derived the number through consensus. Table A1 is the normalised matrix that was derived from Table 1 (pair-wise comparison) in order to derive the relative importance of the stakeholders for supplier performance evaluation. Table A1 reveals that the production department received highest importance followed by quality department.

\section{$<$ INSERT Table 1 ABOUT HERE>}

\section{Step 3: Identifying stakeholders' requirements}

Each stakeholder's requirements was then identified through brainstorming with representatives of each department and carefully validated through focus group with the involvement of representatives from each functional department. The stakeholders' requirements as identified by the groups were 'compliance with industry standards', 'compliance with social and environmental', 'Electronic Data Interchange (EDI)', 'established business and financial stability', 'quality', 'organisational image and financial performance', 'reliability of order fulfilment', 'risk management capacity / strategy', and 'open book costing (costing transparency)'.

\section{Step 4: Forming the first House of Quality (HoQ-I) with the stakeholders ('what') and their requirements ('how')}

The importance of each stakeholder's requirements was derived using $0-9$ scale ( 9 being the strongest relationship between stakeholders and their requirements and 0 being no relationship) through focus groups. Table A2 shows the co-relation between stakeholders and their requirements.

The relative importance of each stakeholder's requirements was derived through normalisation (dividing each cell with the sum of the row). Table 2 depicts the first House of Quality (HoQ-I) with 'stakeholders' in place of 'what' and 'stakeholders' requirements' in 
place of 'how'. The relationship between stakeholders and their requirements is the relative importance of each stakeholder's requirement that was derived through normalisation. The global priority of each requirement was derived by multiplying importance of each stakeholder and relative importance of the stakeholder's requirement. The overall importance of each stakeholder requirement was determined by adding the global priority across the column. It has been observed that quality has been given highest importance followed by reliability of order fulfilment, established business and financial stability, risk management capability, compliance with industry standard, compliance with environmental and social aspects, total cost ownership, and organisational image. The lowest emphasize was given to EDI activities.

\section{$<$ INSERT Table 2 ABOUT HERE>}

\section{Step 5: Identification of criteria and sub-criteria for supplier performance evaluation, and forming a hierarchical framework}

Both strategic and tactical level process maps were developed with the close cooperation from the representatives of the process owners of the organisation. Figure A1 depicts the strategic business process with four major sub-processes - business opportunity assessment, product design, product manufacturing, and after sales activities. The detailed process maps in tactical level are appended to Figures A2 to A4. The process maps are made available to the participants to identify the criteria and sub-criteria for supplier evaluation. A focus group was formed with the representatives of each functional stakeholder. They identified quality and cost performance criteria for supplier performance evaluation to facilitate business opportunity assessment process. Quality, delivery and cost performance along with environmental, social and risk management practices, and organisational capability criteria for suppliers' evaluation were considered for product design and planning process. Only quality and delivery performance, and risk management practices criteria for supplier evaluation were considered for production process. After sales activities need suppliers' commitment to both environmental and risk management practices. Collectively for the entire business, they identified seven criteria - three supplier performance criteria (quality, delivery and cost) and four practices and capability (environmental, social, risk and organisational capability) criteria. The performance criteria are lagging (reactive) factors and the capability and practice criteria are leading (proactive) factors. The focus group further classified the criteria to several subcriteria. The criteria and sub-criteria for supplier performance evaluation are illustrated in Figure 2 in hierarchical order.

$<$ INSERT Figure 2 ABOUT HERE $>$

\section{Step 6: Forming of the second House of Quality (HoQ-II) with 'stakeholders' requirements' as 'what' and 'sub-criteria for supplier evaluation' as 'how'}

The same focus group was then entrusted to develop relationship between stakeholders' requirements and the sub-criteria as identified in previous step. A $0-9$ scale ( 0 being no relationship and 9 being strongest relationship) was used to develop the relationship matrix 
(Table 3). The relative importance of the sub-criteria with respect to each stakeholder's requirement was calculated through normalisation across the rows. The second House of Quality (HoQ-II) was then formed (Table 3) and the overall importance of sub-criteria were derived by multiplying the importance of each stakeholder's requirement with corresponding importance of sub-criteria and adding them across the column (Table A3, Table A4). The relative importance of the sub-criteria has been shown in percentage. The concerned organisation had given highest importance to quality of products, and delivery reliability and flexibility. Organisational image, management commitment, past performance, and risk management practices were also given higher importance than other sub-criteria.

$<$ INSERT Table 3 ABOUT HERE>

\section{Step 7: Gathering information on supplier performance against each sub-criterion}

The procurement department was entrusted to gather and collate information on concerned suppliers' performance against each sub-criterion. They had considered three strategic suppliers - wool, chemical/dyes, and yarn manufacturers for this study. A detailed structured database was developed (Table 4) on supplier performance against each sub-criteria and made available to all participating stakeholders to enable them to make the basis for pairwise comparison of supplier performance evaluation.

\section{$<$ INSERT Table 4 ABOUT HERE>}

Step 8: Formation of the third and last House of Quality (HoQ-III) with 'supplier performance evaluation sub-criteria' as 'what' and 'suppliers' as 'how' to determine relative performance of suppliers

Using the information as developed in step 7, the stakeholders' representatives were asked to pair-wise compare participating supplier performance against each sub-criterion in the AHP framework. The outcome of the analysis was then used to form the HoQ-III as depicted in Table 5. The overall performance of each supplier was then derived by multiply the importance of sub-criteria with each supplier performance against that criteria and adding across the column (Table 6). Figures 3 and 4 depict the relative performance of each supplier against each sub-criterion and overall performance of each participating supplier respectively. Supplier 1 came out as the best performing supplier, followed by the third supplier.

$<$ INSERT Table 5 ABOUT HERE>

$<$ INSERT Table 6 ABOUT HERE>

$<$ INSERT Figure 3 ABOUT HERE>

$<$ INSERT Figure 4 ABOUT HERE>

\section{Step 9: Deriving improvement measures}


Following the performance evaluation, the participants came out with a list of improvement measures for each candidate supplier. Although the overall performance of supplier 1 is better than the other two, their 'continuous quality improvement program' and 'corrective and preventive action system' need attention in order to improve over quality of their products and services. Additionally, consideration of eco-design in every product should be adopted. The major concern of supplier 2 is in the area of their delivery performance and service quality. The organisation has less receptive to changes. Both environmental, social and risk management also need improvement. While supplier 3 does not have major issue in quality of products and services, they also suffer from lack maintaining delivery schedule. However, their major concern is their cost performance and inflexibility to accommodate changes. Both social and risk management also need attention.

\section{Step 10: Implementation of the improvement measures}

The outcome of the supplier performance evaluation was then communicated to the concerned supplier organisations and a discussion was held between the client organisation and the supplier organisations in order to implement the actions suggested. The desired changes have been incorporated by the suppliers in six month period through appropriate business case development. This has been subsequently reviewed by the client organisation. The improvements in performance had positive impact across the supply chain of the four participating organisations.

The client organisation reviewed the effectiveness of the supplier performance evaluation technique after three months from the day of implementation of the suggested changes. A workshop was conducted to see how the implemented method worked in the firm. In the workshop nine key players of the organisation were asked to provide feedback, using a 1 to 5 scale, on the effectiveness of the supplier performance evaluation technique and its impact on operational performance and business success (Table A5). Five judging criteria were selected by the key players in order to determine the effectiveness of the supplier performance technique. These were realism, capability, flexibility, ease of use and cost of implementing the supplier evaluation technique. 'Realism' criterion judges if the implemented technique reflects the reality of the managers' decision situation, including the multiple objectives of both the firm and its managers. The 'capability' criterion judges if the technique is able to deal with multiple time periods, simulate various situations both internal and external to the project, and optimise the managerial decision. The 'flexibility' criterion helps to determine if the technique provides meaningful results within the range of conditions that the firm might experience. This criterion judges if the supplier selection technique has the ability to be easily modified, or to be self-adjusting in response to change in the firm's environment. 'Ease of use' is another judging criterion to check if the technique is reasonably convenient, does not take a long time to execute, and is easy to use and understand by the decision makers. Finally, the 'cost' criterion judges if the data gathering and modelling costs are low relative to the cost of the project and these are less than the potential benefits of the project. 
A statistical analysis was performed to examine the reliability and internal consistency of the weights provided by the interviewees on the three factors. Reliability statistics on the responses of the key players (Table A5), intra-class correlation test, and F-test were conducted for the three factors. The reliability analysis (Table 7) helped to examine reliability of the weights and internal consistency among the criteria under a factor. Intra-factor correlation test (Table 8) considered the two-way mixed effects model where people effects were random and 'measures' effects were fixed.

\section{$<$ INSERT Table 7 ABOUT HERE $>$ $<$ INSERT Table 8 ABOUT HERE $>$}

From this statistical analysis it was established that the consistencies of the weights provided by the interviewees on the three measuring attributes were within acceptable range. The inter-class correlation coefficient table (Table 8) clearly indicate that there was significant correlation (as Sig. $<0.050$ ) among the criteria under each factor.

Subsequently, a validation survey was conducted among the representatives of client organisation, supplier and customer organisation. They have been asked on the user friendliness of the approach, effectiveness of the QFD-AHP scoring method for supplier evaluation, and overall business benefits. Additionally, they have been asked when the method could be applied, how much readiness is required for effective implementation, and how to measure the successful implementation of the performance measurement model. All the questions were asked individually through interviews via telephone or in person. Operational director, purchase manager, production manager, quality manager and marketing manager of the carpet manufacturing organisation were interviewed. Additionally, three sales managers of three supplier organisations, a contract manager of an airport authority (customer organisation) and a purchase manager of cruise ship operator (customer organisation) gave the interviews. Although all of them were quite positive for its implementation and adoption, they indicated that number of issues needed to be addressed for successful adoption of the performance measurement model.

The operational director of the carpet manufacturing said:

"We have more than twenty strategic suppliers and our business success greatly depends on their performance. They are part of our business processes. We are customised commercial carpet manufacturer. Hence, their resilience often helps us to achieve our customers' satisfaction. We evaluate our suppliers mainly through time, cost and quality criteria, but this has limitation. We have suffered from suppliers' non-achievement in the past and I am sure that adopting the proposed model will help us working with the more competent suppliers with stronger relationship".

The purchase manager responded:

"The model would be applied every three months to review the strategic suppliers' performance. However, the identification of the criteria and their importance will be reviewed once in every year". 
The production manager said:

"The framework is good, but needs experienced facilitators to implement as the effectiveness of the model will depend on identifying right criteria and determining appropriate importance for each. Additionally, the suppliers are also to be motivated for improving their performance".

The contract manger of the airport authority narrated:

"The competent suppliers of the manufacturing organisation help in dealing with a number issues during production (e.g. scope and specification changes that are inevitable). Additionally, they also help substantially during after sales services period. However, these could be expensive options".

The purchase manager of the cruise ship operator indicated:

"Carpets made from eco-friendly materials have more appeal to our customers and we can recycle the materials quite easily."

The procurement manager of one of the supplier organisations said:

"The model informs us quite objectively on clients' requirements and gives them a basis for our price quote. We also can improve our performance through benchmarking with the best organisations in the industry It improves buyer - supplier relationship".

Another procurement manager of supplier organisation commented:

"This is quite client driven approach. We have little to contribute. The approach is time consuming and the improvement projects are cost intensive. The return is not assured although in theory supply chain is likely to gain".

\section{Discussion}

Supplier performance evaluation has been researched extensively. Although various management science tools and techniques have been applied to measure supplier performance and suggest improvement, very few studies have linked the criteria for supplier performance evaluation with the strategic intents of the organisations. The integrated QFD-AHP method for supplier performance evaluation links organisations' strategic intents with the criteria for supplier evaluation through identifying the stakeholders and their requirements along with their importance in supplier performance evaluation. In this study, importance of the stakeholders' requirements is determined through developing relationship matrix between stakeholders and their requirements, and normalisation approach, unlike by pair-wise comparison of the requirements of Ho et al. (2011) as there were too many stakeholders' requirements against each stakeholder. Inconsistency increases in pair-wise comparison if there are many elements to compare. Similarly, the importance of the sub-criteria were also determined not through pair-wise comparison but using correlation matrix approach followed by normalisation. Finally, each supplier performance against each sub-criterion was derived through pair-wise comparison in the AHP framework. Additionally, the criteria and sub-criteria for supplier performance evaluation were identified using process maps in strategic and tactical levels 
respectively. Supplier performance measurement constructs have been linked with business processes and their metrics. The process maps (Figures A2, A3 and A4) also help to identify criteria for supplier selection by relating suppliers' contribution in achieving process performance parameters.

Traditionally, quality, delivery schedule, and price are considered as major criteria for supplier performance evaluation. More recently, some holistic criteria like organisational image, past performance, and business stability are also used in many researches. This study through stakeholders' involvement identifies quality performance, cost performance, delivery performance, organisational capability, environmental practices, social practices and risk management practices as major criteria for supplier performance evaluation, and divides them into number of sub-criteria. While quality performance, cost performance, and delivery performance are lagging factors; organisational capability, environmental practices, social practices and risk management practices are leading factors. These criteria have been used in prior studies as shown in Table A6. However, this study systematically identifies them through active participation of the stakeholders of the entire supply chain with the consideration of supply chain processes in tactical level and process parameters. On one hand, these criteria are linked with stakeholders' requirements and on the other hand, they develop synergy with the business processes in order to enhance supply chain performance. Identifying the most appropriate criteria for supplier performance evaluation has significance in improving supplier performance as unless the right criteria are considered, even a very sophisticated method for performance measurement will not be of any use. Therefore, this study contributes by not only identifying both leading and lagging criteria for supplier performance evaluation but also a method of identifying appropriate criteria that could be applied in any industry for different purposes.

Critical Success Factor (CSF) of an organisation depends on the type of industry, its customers, leading and lagging factors governing the overall performance of the enterprise, internal and external stakeholders, and their requirements. It is evident from the intra-factor correlation test (Table 8) that correlation among the factors and the criteria under each factor exists. These correlations cause changes in other factors/criteria and can be illustrated in the form of causal relationships which contribute to identifying the CSF of the organisation. In this research, the goals of the enterprise are directed to achieve enhanced supplier performance, operational performance and business success. These goals are related to the disparate routine activities of the enterprise. There are straightforward relationships among the goals and the activities of the enterprise (Figure 5). The relationships among the lagging (reactive) and leading (proactive) factors (Figure 2) are closely examined. It is found that a causal relationship exists among the quality performance factors and business success (Figure 6). Similarly, a causal relationship is found among the delivery performance factors and enterprise's operational performance attributes (Figure 7). The costing performance factors (Figure 2) and enterprise's business success attributes hold strong relationships (Figure 8). From the research it is noticed that the supplier performance attributes are closely related to the proactive factors of Figure 2. This causal relationship is illustrated in Figure 9. Finally, causal relationship is found among the stakeholders' requirements (Table 8) and the goals of the 
enterprise (Figure 10). The causal relationships depicted in this article are based on the relative causal effects.

$$
\begin{aligned}
& <\text { INSERT Figure } 5 \text { ABOUT HERE }> \\
& <\text { INSERT Figure } 6 \text { ABOUT HERE }> \\
& <\text { INSERT Figure } 7 \text { ABOUT HERE> } \\
& <\text { INSERT Figure } 8 \text { ABOUT HERE> } \\
& <\text { INSERT Figure } 9 \text { ABOUT HERE> } \\
& <\text { INSERT Figure } 10 \text { ABOUT HERE> }
\end{aligned}
$$

The case study organisation, subsequent to implementing the proposed supplier performance measurement system achieved number of business successes - started manufacturing in China, developed long term relationship with their suppliers in India, Bangladesh and New Zealand, won number for competitive bids for several airports across the Globe. Additionally, they had acquired more than one month deferred payment from couple of their strategic suppliers in India and Bangladesh. In view of the above, it could be stated that the proposed approach to supplier performance measurement bears one of the positive impacts on organisational overall performance.

The model has a few shortcomings. Strategic supplier performance evaluation has to be dynamic as business environment constantly changes. Therefore, the model should be flexible enough to accommodate the desired changes in factors and sub-factors for supplier evaluation and performance measurement. Additionally, the method for performance evaluation might also need to amend according to the number and characteristics of the factors and sub-factors. Incorporating these changes dynamically is not only complicated but also time consuming. However, if the model is designed with adequate flexibility these issues could be resolved in a relatively easier manner. Acquiring consensus of concerned stakeholders is always challenging. As the model's effectiveness depends on the quality of responses a most appropriate methodology has to be adopted and this will not only vary across organisations and industries but also across time frame.

\section{Conclusions}

Strategic supplier performance evaluation is one of the important functions within supply chain. The integrated QFD-AHP method for supplier evaluation is effective, but it needs a customised approach to adopt it within the industry. Subsequent to adoption of the proposed supplier performance evaluation model, the company has observed substantial improvement of supplier performance in time, cost and delivery along with organisational capability factors that helped them to reduce supply chain cost and improve service level. This has resulted very positive impact on their operational performance (e.g. reduction of inventory and waste in every stage of production) and they could expand their business in BRIC countries (e.g. manufacturing in China and India and establishing market there as well). The stakeholders' buy in is critical in order to implement the improvement measures. The leading factors (organisational capability and practices) help achieve superior performance (e.g. quality, 
delivery and cost). It reveals that measuring supplier performance using only quality, delivery and cost criteria will not help to improve supply chain performance. Improving suppliers' organisational capability and practices will lead to achieve superior business performance of client organisations along with enhancing overall supply chain performance.

A potential future research could be replicating this case-based action research across a broader periphery of manufacturing firms in the UK as well as abroad. Another area for future study might be the evolution of supplier selection over time. Dynamicity of this decision is another thrust area. Therefore, further research should be focused on other metrics and enhancement of criteria for analysis and fast re-analysis of suppliers considering dynamics of the operational environment. A dynamic QFD approach may bring new facets of the problem. In this research the imprecision of the linguistic subjective factors are not taken into consideration. This aspect can be addressed using fuzzy sets. Dependency among the factors/criteria of the supply chain should be investigated and may be presented in the form of a structured network. Vulnerability of the factors within a supply chain network is another issue that should be addressed. Scope for further research includes examination of the critical success factors for an industrial sector, by clustering industries of similar types. A statistical examination using structural equation modelling could be of help when the causal relationships among the factors/criteria are considered. This would fortify the outcome of the implemented case. Additionally, a case-based approach could be adopted for analysing supply chain issues of any organisation using causal relationship and statistical methods (e.g. factor analysis).

\section{Acknowledgements}

The authors sincerely convey their thanks to the anonymous reviewers and Professor Edwin Cheng (Asian-Pacific Editor) for their constructive comments all through the review process. The authors also acknowledge the contributions of British Council for funding this project under UK India Education Research Initiative (UKIERI) and the executives of anonymous British manufacturing organisation, who have provided primary information for this research paper. 


\section{References}

Amid, A., Ghodsypour, S. H. and O’Brien, C., 2011. A weighted max-min model for fuzzy multi-objective supplier selection in a supply chain. International Journal of Production Economics, 131 (1), 139-145.

Ansari, A. and Modarress, B., 1994. Quality function deployment: the role of suppliers. International Journal of Purchasing and Materials Management, 30 (3), 27-35.

Azadeh, A. and Alem, S.M., 2010. A flexible deterministic, stochastic and fuzzy data envelopment analysis approach for supply chain risk and vendor selection problem: Simulation analysis. Expert Systems with Applications, 37 (12), 7438-7448.

Bevilacqua, M., Ciarapica, F.E. and Giacchetta, G, 2006. A fuzzy-QFD approach to supplier selection. Journal of Purchasing and Supply Management, 12 (1), 14-27.

Bhattacharya, A., Mohapatra, P., Kumar, V., Dey, P.K., Brady, M., Tiwari, M.K. and Nudurupati, S.S., 2014. Green supply chain performance measurement using fuzzy ANPbased balanced scorecard: a collaborative decision-making approach. Production Planning \& Control: The Management of Operations, 25 (8), 698-714.

Bhattacharya, A., Geraghty, J. and Young, P., 2010. Supplier selection paradigm: An integrated hierarchical QFD methodology under multiple-criteria environment. Applied Soft Computing, 10 (4), 1013-1027.

Bhattacharya, A., Sarkar, B. and Mukherjee, S.K., 2005. Integrating AHP with QFD for robot selection under requirement perspective. International Journal of Production Research, 43 (17), 3671-3685.

Chai, J., Liu, J.N.K. and Ngai, E.W.T.,2013. Application of decision-making techniques in supplier selection: a systematic review of literature. Expert Systems with Applications, 40 (10), 3872-3885.

Chan, F.T.S., Kumar, N., Tiwari, M.K., Lau, H.C.W. and Choy, K.L., 2008. Global supplier selection: a fuzzy-AHP approach. International Journal of Production Research, 46 (14), $3825-3857$.

Chan, F.T.S., Qi, H.J., Chan, H.K., Lau, H.C.W. and Ip, R.W.L., 2003. A conceptual model of performance measurement for supply chains. Management Decision, 41 (7), 635-642.

Chen, C.-C., 2009. Integration of quality function deployment and process management in the semiconductor industry. International Journal of Production Research, 47 (6), 14691484.

Chen, Y.-J., 2011. Structured methodology for supplier selection and evaluation in a supply chain. Information Sciences, 181 (9), 1651-1670.

Chen, T.-Y., Wang, H.-P. and Lu, Y.-Y., 2011a. A multicriteria group decision-making approach based on interval-valued intuitionistic fuzzy sets: a comparative perspective. Expert Systems with Applications, 38 (6), 7647-7658.

Chen, Y.-H., Wang, T.-C. and Wu, C.-Y., 2011b. Strategic decisions using the fuzzy PROMETHEE for IS outsourcing. Expert Systems with Applications, 38 (10), 1321613222.

Demirtas, E.A. and Üstün, Ö., 2008. An integrated multi-objective decision making process for supplier selection and order allocation. Omega, 36 (1), 76-90. 
Demirtas, E.A. and Üstün, Ö, 2009. Analytic network process and multi-period goal programming integration in purchasing decisions. Computers and Industrial Engineering, 56 (2), 677-690.

Estampe, D., Lamouri, S., Paris, J.-L. and Brahim-Djelloul, S., 2013. A framework for analysing supply chain performance evaluation models. International Journal of Production Economics, 142 (2), 247-258.

Faez, F., Ghodsypour, S.H. and O'Brien, C., 2009. Vendor selection and order allocation using an integrated fuzzy case-based reasoning and mathematical programming model. International Journal of Production Economics, 121 (2), 395-408.

Fawcett, S.E. and Cooper, M.B., 1998. Logistics performance measurement and customer success. Industrial Marketing Management, 27 (4), 341-357.

Ferreira, L. and Borenstein, D., 2012. A fuzzy-bayesian model for supplier selection. Expert Systems with Applications, 39 (9), 7434-7844.

Galt, J.D.A. and Dale, B.G., 1991. Supplier development: a British case study. International Journal of Purchasing and Materials Management, 27 (1), 16-22.

Goffin, K., Szwejczewski, M. and New, C., 1997. Managing suppliers: when fewer can mean more. International Journal of Physical Distribution and Logistics Management, 27 (7), 422-436.

Guneri, A.F., Ertay, T. and Yücel, A., 2011. An approach based on ANFIS input selection and modelling for supplier selection problem. Expert Systems with Applications, 38 (12), 14907-14917.

Guo, X., Yuan, Z. and Tian, B., 2009. Supplier selection based on hierarchical potential support vector machine. Expert Systems with Applications, 36 (3), Part 2, 6978-6985.

Ho, W., Dey, P.K. and Lockström, M., 2011. Strategic sourcing: a combined QFD and AHP approach in manufacturing. Supply Chain Management: An International Journal, 16 (6), 446-461.

Ho, W., Xu, X. and Dey, P.K., 2010. Multi-criteria decision making approaches for supplier evaluation and selection: a literature review. European Journal of Operational Research, 202 (1), 16-24.

Holmberg, S., 2000. A system perspective on supply chain measurements. International Journal of Physical Distribution \& Logistics Management, 30 (10), 847-868.

Hsu, B.-M., Chiang, C.-Y. and Shu, M.-H., 2010. Supplier selection using fuzzy quality data and their applications to touch screen. Expert Systems with Applications, 37 (9), 61926200 .

Jadidi, O., Zolfaghari, S. and Cavalieri, S., 2014. A new normalized goal programming model for multi-objective problems: A case of supplier selection and order allocation. International Journal of Production Economics, 148, 158-165.

Kaufmann, L., Kreft, S., Ehrgott, M. and Reimann, F., 2012. Rationality in supplier selection decisions: the effect of the buyer's national task environment. Journal of Purchasing and Supply Management, 18 (2), 76-91.

Kull, T.J. and Talluri, S., 2008. A supply risk reduction model using integrated multicriteria decision making. IEEE Transactions on Engineering Management, 55 (3), 409-419. 
Kuo, R.J. and Lin, Y.J., 2012. Supplier selection using analytic network process and data envelopment analysis. International Journal of Production Research, 50 (11), 28522863.

Lee, C.C. and Ouyang, C., 2009. A neural networks approach for forecasting the supplier's bid prices in supplier selection negotiation process. Expert Systems with Applications, 36 (2), 2961-2970.

Lehmann, D.R. and O'Shaughnessy, J., 1982. Decision criteria used in buying different categories of products. Journal of Purchasing Materials and Management, Spring, 9-14.

Levary, R.R., 2008. Using the analytic hierarchy process to rank foreign suppliers based on supply risks. Computers and Industrial Engineering, 55 (2), 535-542.

Li, L. and Zabinsky, Z.B., 2011. Incorporating uncertainty into a supplier selection problem. International Journal of Production Economics, 134 (2), 344-356.

Lin, R.-H., 2012. An integrated model for supplier selection under a fuzzy situation. International Journal of Production Economics, 138 (1), 55-61.

Lin, C.-T., Chen C.-B. and Ting, Y.-C., 2011. An ERP model for supplier selection in electronics industry. Expert Systems with Applications, 38 (3), 1760-1765.

Lin, Y.-T., Lin, C.-L., Yu, H.-C., \& Tzeng, G.-H., 2010. A novel hybrid MCDM approach for outsourcing vendor selection: a case study for a semiconductor company in Taiwan. Expert Systems with Applications, 37 (7), 4769-4804.

Medori, D. and Steeple, D., 2000. A framework for auditing and enhancing performance measurement systems. International Journal of Operations \& Production Management, $20(5), 520-533$.

Minahan, T.A. and Vigoroso, M.W., 2002. The supplier performance measurement benchmarking report. iSource Business magazine, December, 1-22. Source: http://www.lyonsinfo.com/_resources/Aberdeen_SPMS_Report.pdf, Accessed on 7 October 2012.

Montazer, G.A., Saremi, H.Q. and Ramezani, M., 2009. Design a new mixed expert decision aiding system using fuzzy ELECTRE III method for vendor selection. Expert Systems with Applications, 36 (8), 10837-10847.

Narasimhan, R., Talluri, S. and Mendez, D., 2001. Supplier evaluation and rationalization via data envelopment analysis: an empirical examination. Journal of Supply Chain Management, 37(3), 28-37.

Quayle, M., 2002. Purchasing in small firms. European Journal of Purchasing and supply Management, 8 (3), 151-159.

Rich, N., 1995. The use of QFD for relationship assessment and supplier development: adversary, associate, or partner? Paper presented at the fourth International Conference of IPSERA 1995, The University of Birmingham, Birmingham.

Saaty, T.L., 1977. A scaling method for priorities in hierarchical structures. Journal of Mathematical Psychology, 15 (3), 234-281.

Saaty, T.L., 1990. How to make a decision: the analytic hierarchy process. European Journal of Operational Research, 48 (1), 9-26.

Saaty, T.L., 1994. How to make a decision: the analytic hierarchy process. Interfaces, 24 (6), $19-43$ 
Saen, R.F., 2010. Developing a new data envelopment analysis methodology for supplier selection in the presence of both undesirable outputs and imprecise data. International Journal of Advanced Manufacturing Technology, 51 (9-12), 1243-1250.

Schmitz, J. and Platts, K.W. 2004. Supplier logistics performance measurement: indication from a study in the automotive industry. International Journal of Production Economics, 89 (2), 231-243.

Scott, J.A., Ho, W. and Dey, P.K., 2013. Strategic sourcing in the UK bioenergy industry. International Journal of Production Economics, 146 (2), 478-490.

Şen, S., Başligil, H., Şen, C.G. and BaraÇli, H., 2008. A framework for defining both qualitative and quantitative supplier selection criteria considering the buyer-industry. International Journal of Production Research, 46 (7), 1825-1845.

Sevkli, M., 2010. An application of the fuzzy ELECTRE method for supplier selection. International Journal of Production Research, 48 (12), 3393-3405.

Swift, C.O., 1995. Performance for single sourcing and supplier selection criteria. Journal of Business Research, 32 (2), 105-111.

Tsai, Y.L., Yang, Y.J. and Lin, C.-H., 2010. A dynamic decision approach for supplier selection using any colony system. Expert Systems with Applications, 37 (12), 83138321.

Tseng, M., 2011. Green supply chain management with linguistic preferences and incomplete information. Applied Soft Computing Journal, 11 (8), 4894-4903.

Vinodh, S., Anesh Ramiya, R. and Gautham, S.G., 2011. Application of fuzzy analytic network process for supplier selection in a manufacturing organisation. Expert Systems with Applications, 38 (1), 272-280.

Vonderembse, M.A. and Tracey, M., 1999. The Impact of supplier selection criteria and supplier involvement on manufacturing performance. The Journal of Supply Chain Management, 35 (3), 33-39.

Wang, J., Cheng, C. and Huang, K., 2009. Fuzzy hierarchical TOPSIS for supplier selection. Applied Soft Computing Journal, 9 (1), 377-386.

Wilson, E.J., 1994. The relative importance of supplier selection criteria: a review and update. International Journal of Purchasing and Materials Management, 30 (2), 34-41.

$\mathrm{Wu}$, T. and Blackhurst, J., 2009. Supplier evaluation and selection: An augmented DEA approach. International Journal of Production Research, 46 (16), 4593-4608.

Yu, M., Goh, M. and Lin, H., 2012. Fuzzy multi-objective vendor selection under lean procurement. European Journal of Operational Research, 219 (2), 305-311.

Zeydan, M., Colpan, C. and Cobanoglu, C., 2011. A combined methodology for supplier selection and performance evaluation. Expert Systems and Applications, 38 (3), 27412751.

Zhang, X., Lee, C.K.M. and Chen, S., 2012. Supplier evaluation and selection: a hybrid model based on DEAHP and ABC. International Journal of Production Research, 50 (7), 1877 1889. 
Table 1: Importance of stakeholders (pair-wise comparison matrix)

\begin{tabular}{lccccccc}
\hline & $\begin{array}{c}\text { Financial } \\
\text { department }\end{array}$ & $\begin{array}{c}\text { Procurement } \\
\text { Department }\end{array}$ & $\begin{array}{c}\text { Production } \\
\text { Department }\end{array}$ & $\begin{array}{c}\text { Quality } \\
\text { department }\end{array}$ & $\begin{array}{c}\text { Technical } \\
\text { department }\end{array}$ & $\begin{array}{c}\text { Marketing } \\
\text { department }\end{array}$ & $\begin{array}{c}\text { Top } \\
\text { Management }\end{array}$ \\
\hline $\begin{array}{l}\text { Financial } \\
\text { department }\end{array}$ & 1.00 & 0.33 & 0.20 & 0.25 & 0.50 & 0.33 & 2.00 \\
$\begin{array}{l}\text { Procurement } \\
\text { Department }\end{array}$ & 3.00 & 1.00 & 0.33 & 0.50 & 3.00 & 2.00 & 4.00 \\
$\begin{array}{l}\text { Production } \\
\text { Department }\end{array}$ & 5.00 & 3.00 & 1.00 & 2.00 & 4.00 & 3.00 & 5.00 \\
$\begin{array}{l}\text { Quality } \\
\text { department }\end{array}$ & 4.00 & 2.00 & 0.50 & 1.00 & 3.00 & 2.00 & 4.00 \\
$\begin{array}{l}\text { Technical } \\
\text { department }\end{array}$ & 2.00 & 0.33 & 0.25 & 0.33 & 1.00 & 0.50 & 3.00 \\
$\begin{array}{l}\text { Marketing } \\
\text { department }\end{array}$ & 3.00 & 0.50 & 0.33 & 0.50 & 2.00 & 1.00 & 3.00 \\
$\begin{array}{l}\text { Top } \\
\text { Management }\end{array}$ & 0.50 & 0.25 & 0.20 & 0.25 & 0.33 & 0.33 & 1.00 \\
\hline
\end{tabular}




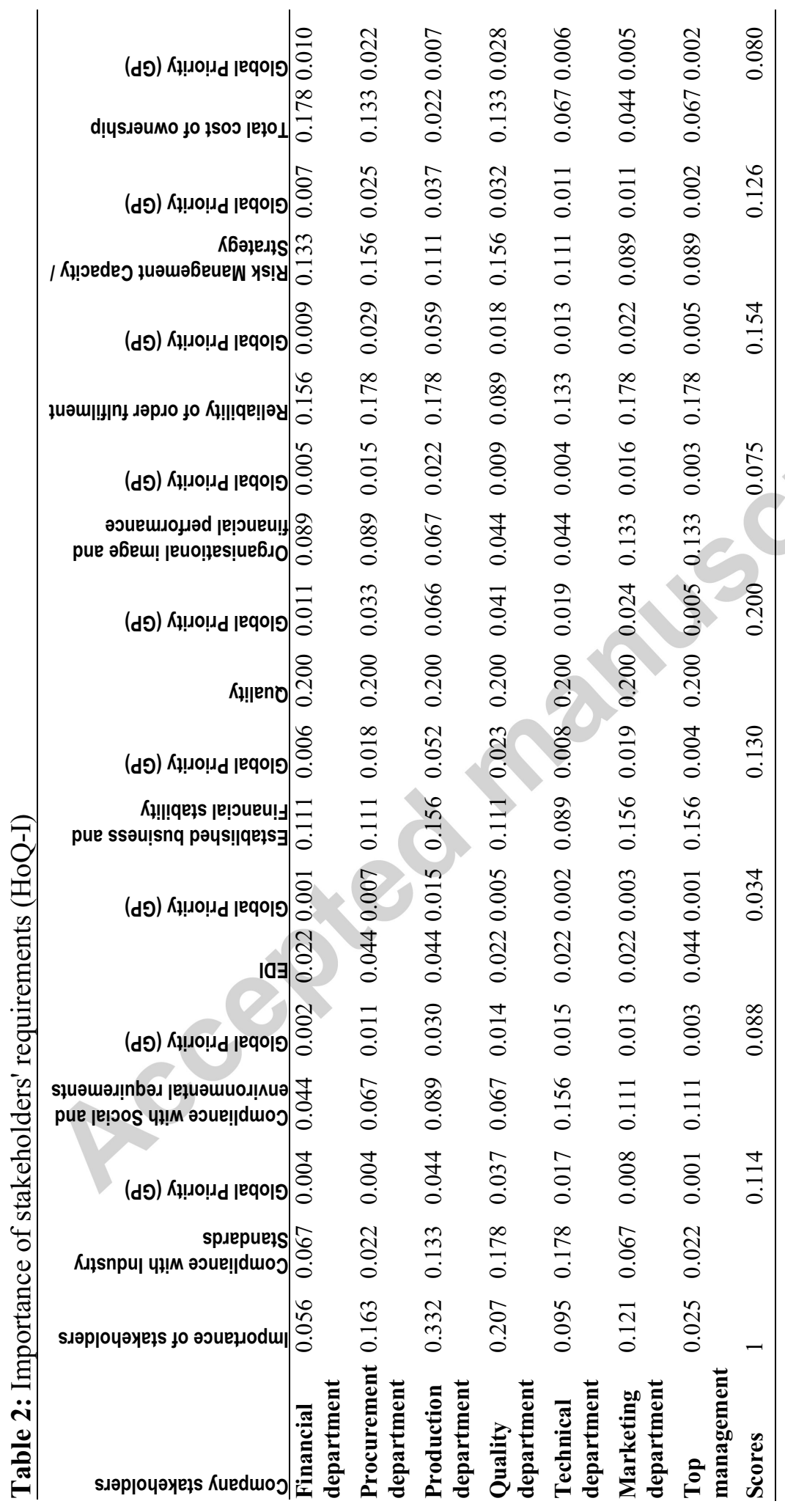




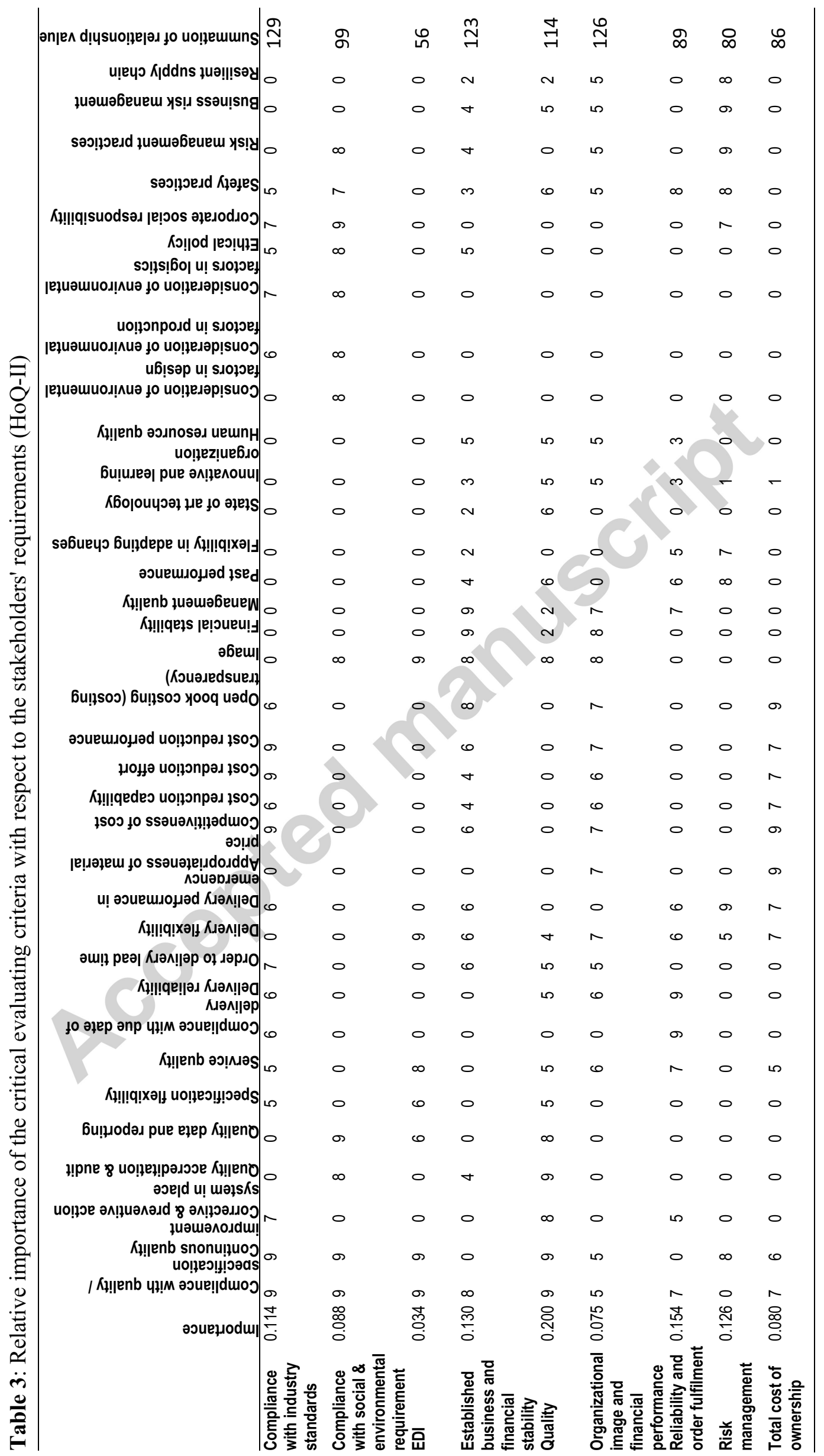




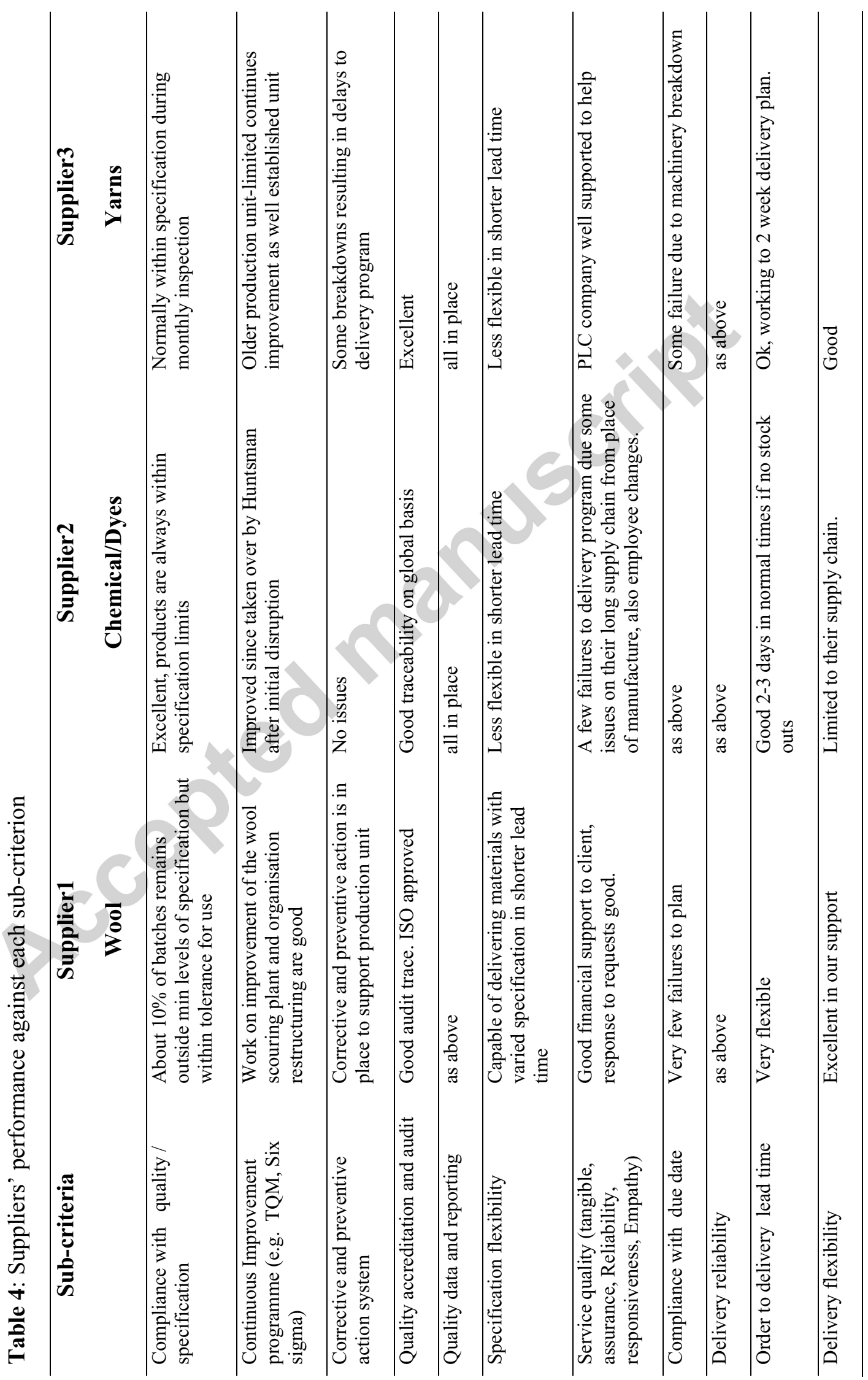




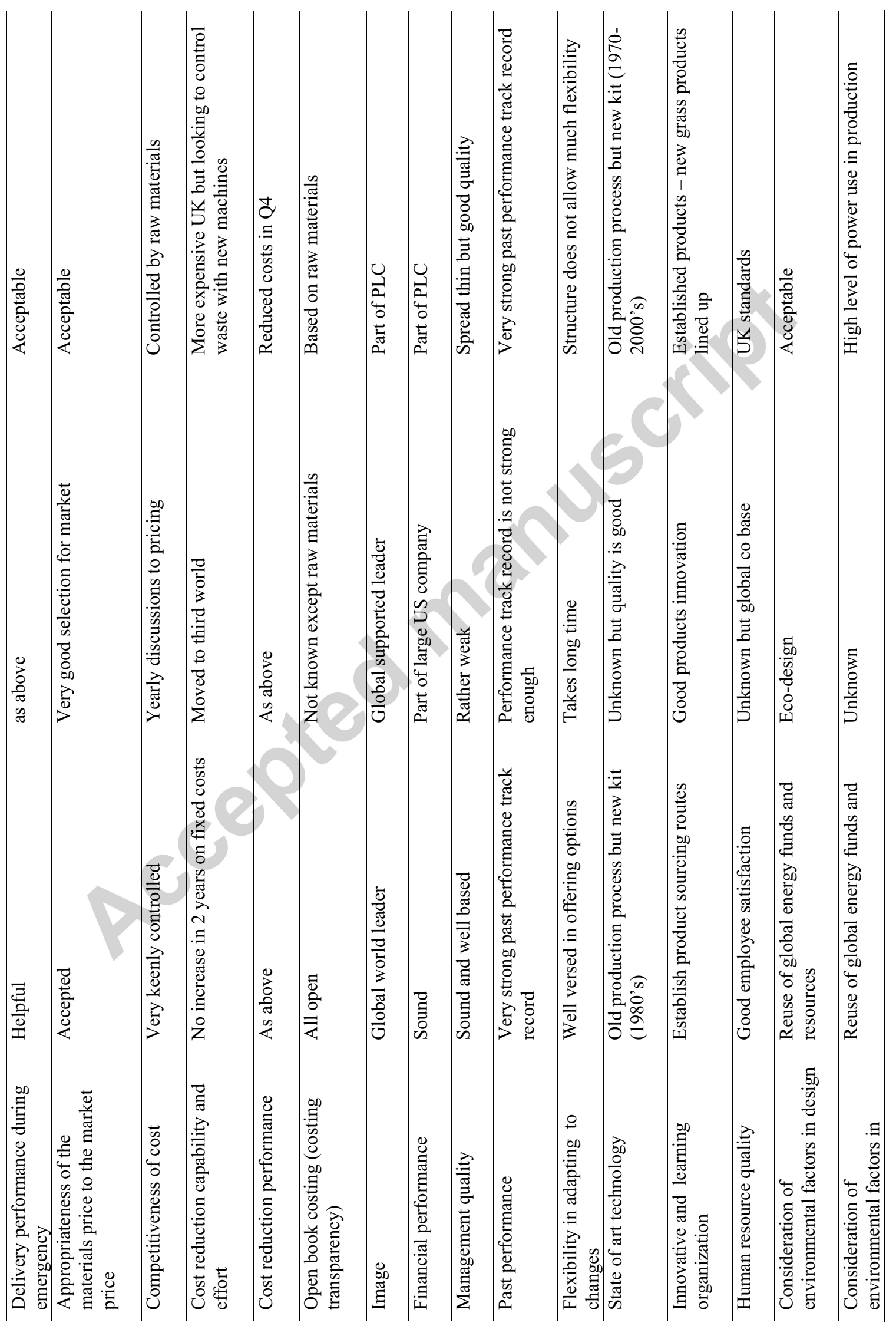




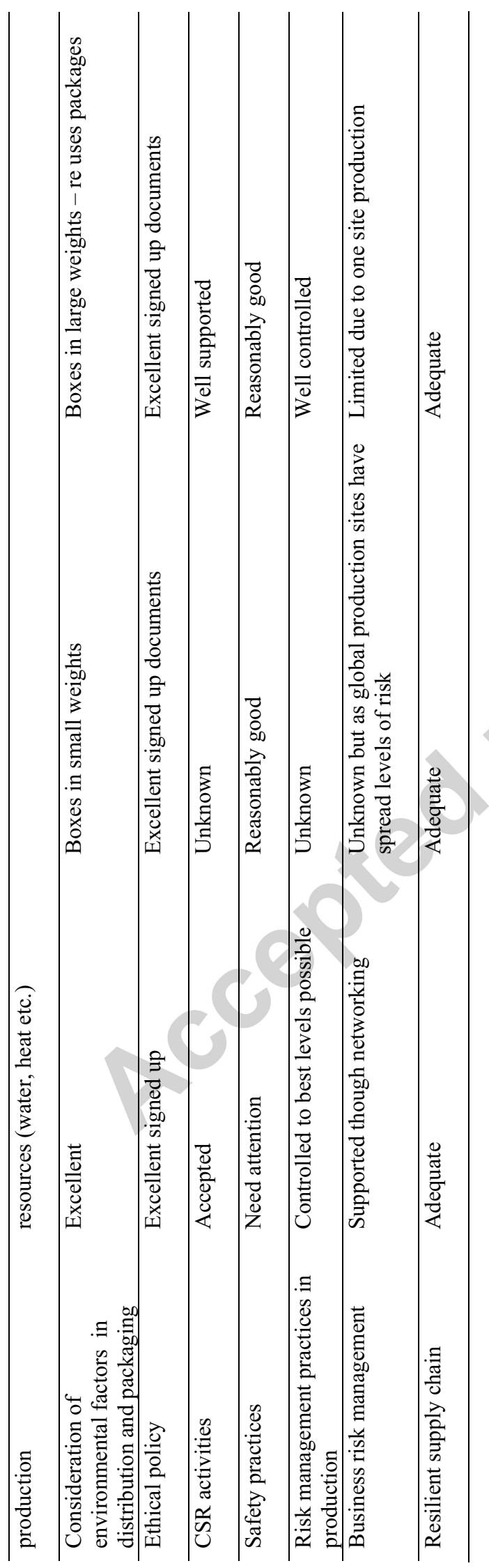




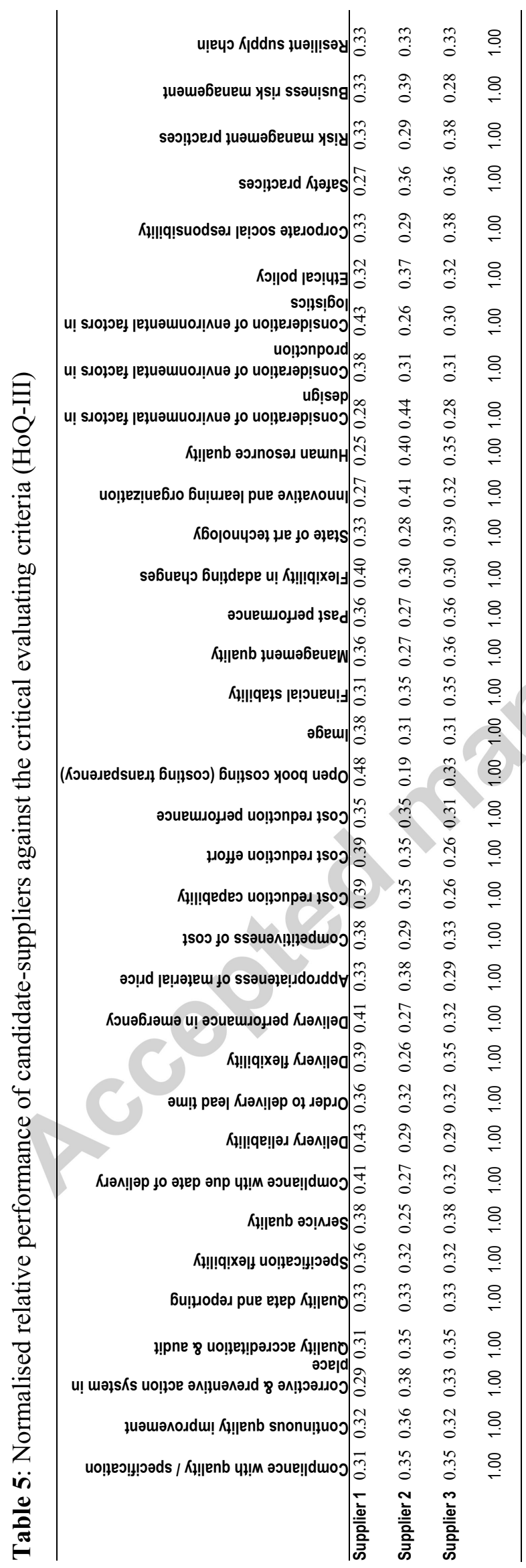




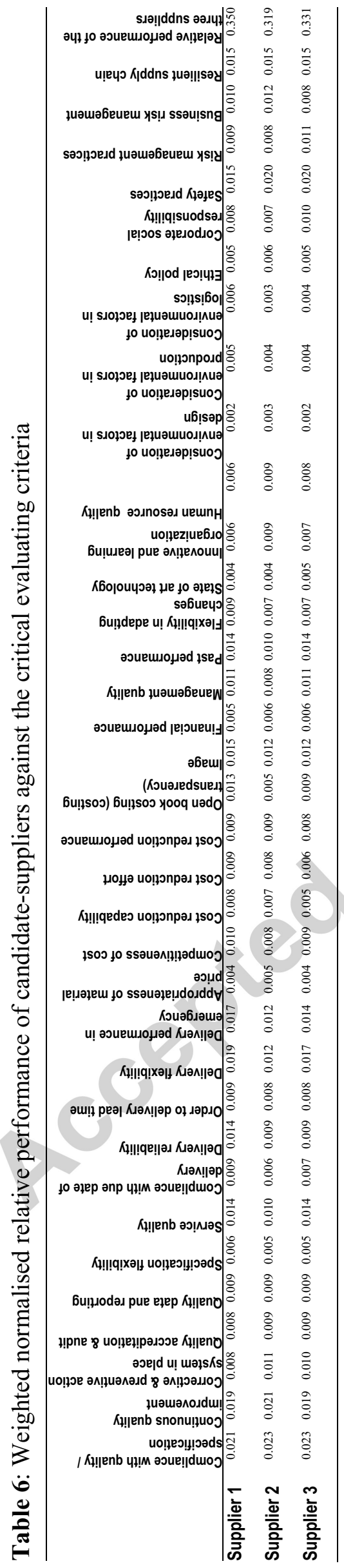


Table 7: Reliability statistics for the key players on the effectiveness/impact of the technique

\begin{tabular}{lllll}
\hline Factors & Cronbach's $\alpha$ & $\begin{array}{l}\text { Cronbach's } \alpha \text { based on } \\
\text { standardised items }\end{array}$ & $\begin{array}{l}\text { 'N' of attributes } \\
\text { in the factor }\end{array}$ & $\begin{array}{l}\text { Internal } \\
\text { consistency/ } \\
\text { Criteria } \\
\text { reliability }\end{array}$ \\
\hline $\begin{array}{l}\text { Supplier } \\
\text { performance }\end{array}$ & 0.638 & 0.679 & 5 & $\begin{array}{l}\text { Acceptable / } \\
\text { Reliable }\end{array}$ \\
$\begin{array}{l}\text { Operational } \\
\text { performance }\end{array}$ & 0.741 & 0.763 & 3 & $\begin{array}{l}\text { Good/ } \\
\text { Reliable }\end{array}$ \\
Business success & 0.688 & 0.661 & & $\begin{array}{l}\text { Acceptable / } \\
\text { Reliable }\end{array}$ \\
\hline
\end{tabular}


Table 8: Intra-factor correlation test

\begin{tabular}{|c|c|c|c|c|c|c|c|c|}
\hline \multirow[t]{2}{*}{ Factors } & \multirow[t]{2}{*}{$\begin{array}{l}\text { Type of } \\
\text { measures }\end{array}$} & \multirow[t]{2}{*}{$\begin{array}{l}\text { Intra-factor } \\
\text { correlation }\end{array}$} & \multicolumn{2}{|c|}{$\begin{array}{c}95 \% \text { Confidence } \\
\text { interval }\end{array}$} & \multicolumn{4}{|c|}{ F-test with true value 0} \\
\hline & & & $\begin{array}{l}\text { Lower } \\
\text { bound }\end{array}$ & $\begin{array}{l}\text { Upper } \\
\text { bound }\end{array}$ & Value & df1 & $\mathrm{df} 2$ & Sig. \\
\hline \multirow[t]{2}{*}{$\begin{array}{l}\text { Supplier } \\
\text { performance }\end{array}$} & $\begin{array}{l}\text { Single } \\
\text { measures }\end{array}$ & $0.261^{b}$ & 0.011 & 0.661 & 2.765 & 8.0 & 32 & 0.019 \\
\hline & $\begin{array}{l}\text { Average } \\
\text { measures }\end{array}$ & $0.638^{\mathrm{c}}$ & 0.052 & 0.907 & 2.765 & 8.0 & 32 & 0.019 \\
\hline \multirow[t]{2}{*}{$\begin{array}{l}\text { Operational } \\
\text { performance }\end{array}$} & $\begin{array}{l}\text { Single } \\
\text { measures }\end{array}$ & $0.488^{\mathrm{b}}$ & 0.072 & 0.831 & 3.857 & 8.0 & 16 & 0.010 \\
\hline & $\begin{array}{l}\text { Average } \\
\text { measures }\end{array}$ & $0.741^{\mathrm{c}}$ & 0.190 & 0.936 & 3.857 & 8.0 & 16 & 0.010 \\
\hline \multirow[t]{2}{*}{$\begin{array}{l}\text { Business } \\
\text { success }\end{array}$} & $\begin{array}{l}\text { Single } \\
\text { measures }\end{array}$ & $0.424^{b}$ & 0.009 & 0.801 & 3.206 & 8.0 & 16 & 0.023 \\
\hline & $\begin{array}{l}\text { Average } \\
\text { measures }\end{array}$ & $0.688^{\mathrm{c}}$ & 0.025 & 0.923 & 3.206 & 8.0 & 16 & 0.023 \\
\hline
\end{tabular}




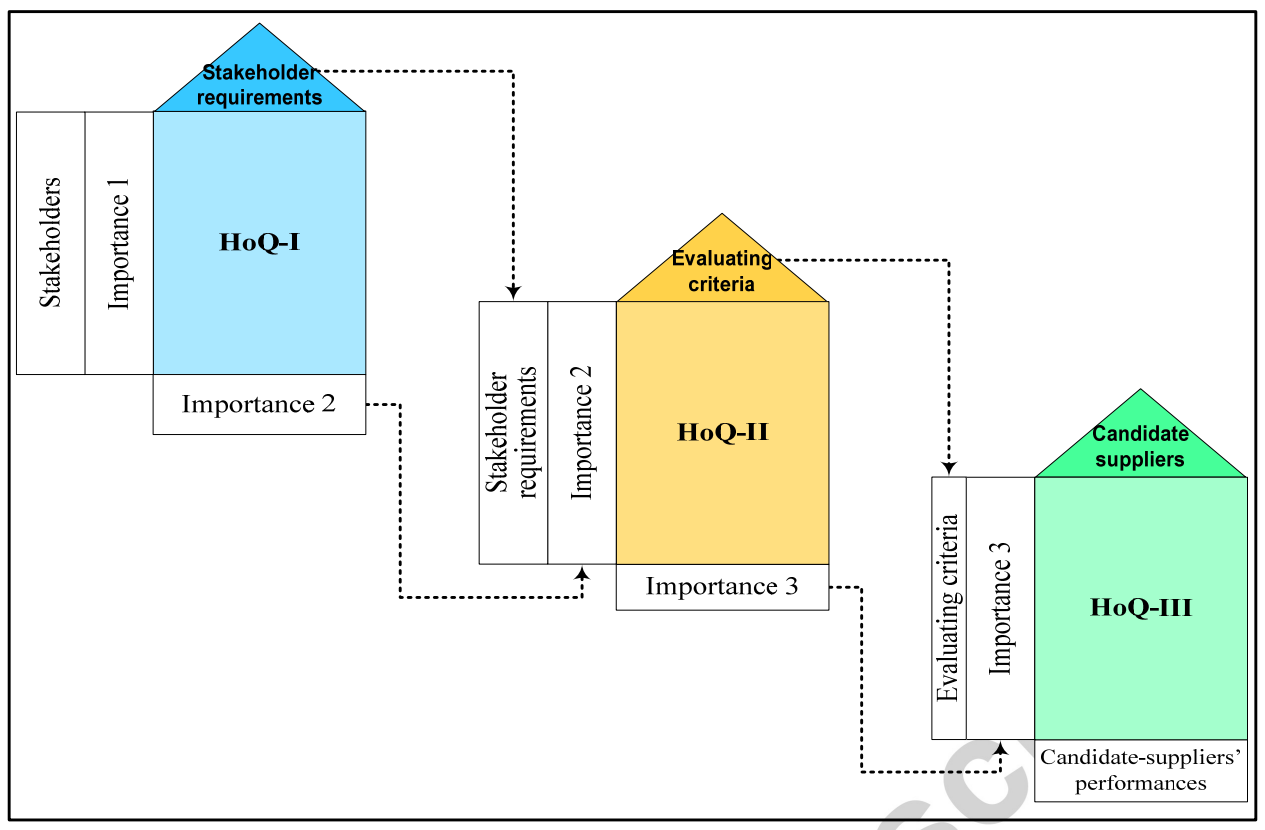

Figure 1: The architecture of the integrated QFD-AHP method (adapted from Ho et al. 2011) 


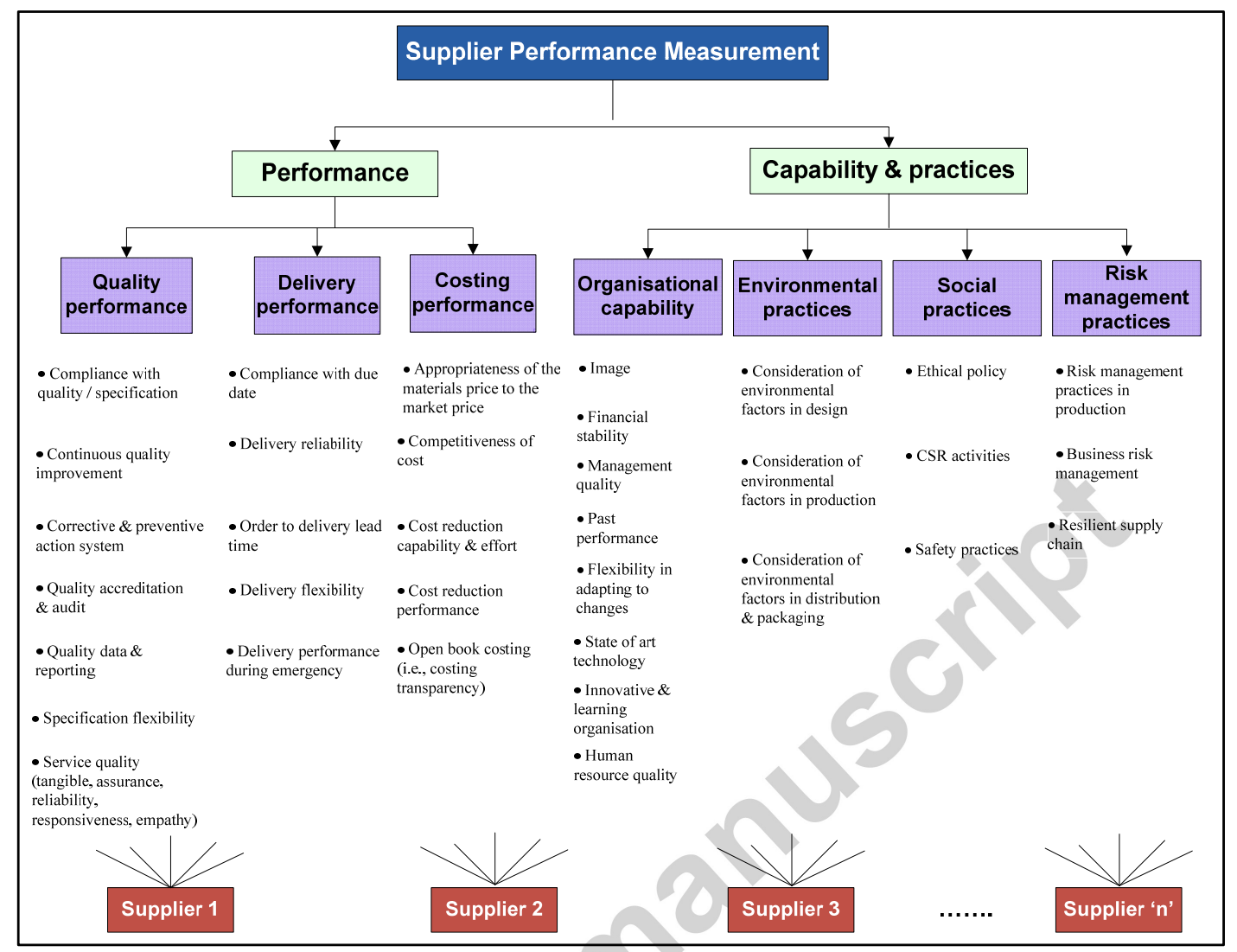

Figure 2: Hierarchical set up of criteria and sub-criteria for evaluating suppliers' performances 


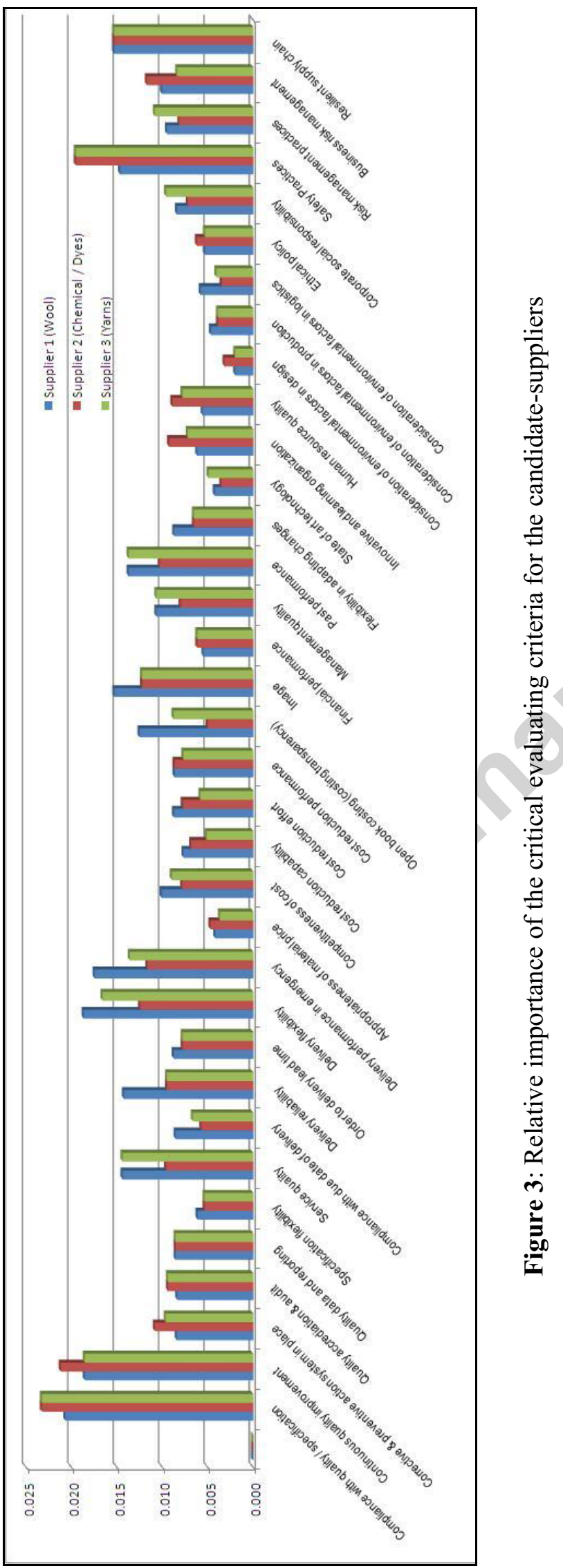




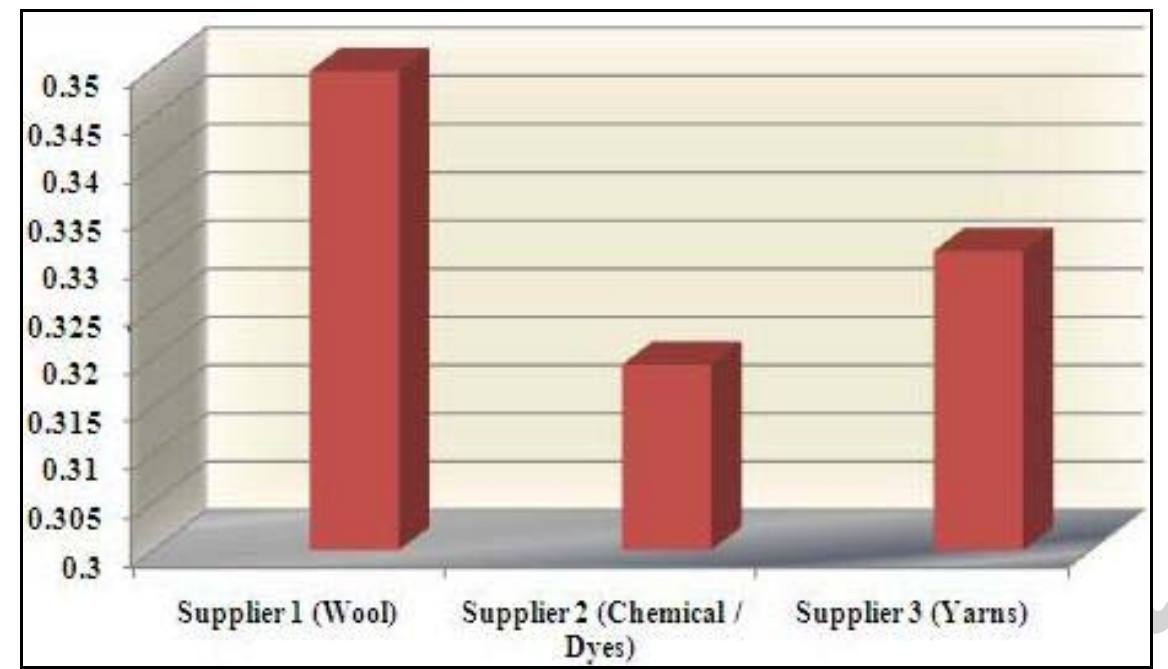

Figure 4: Ranking of the candidate-suppliers based on the performance measures 


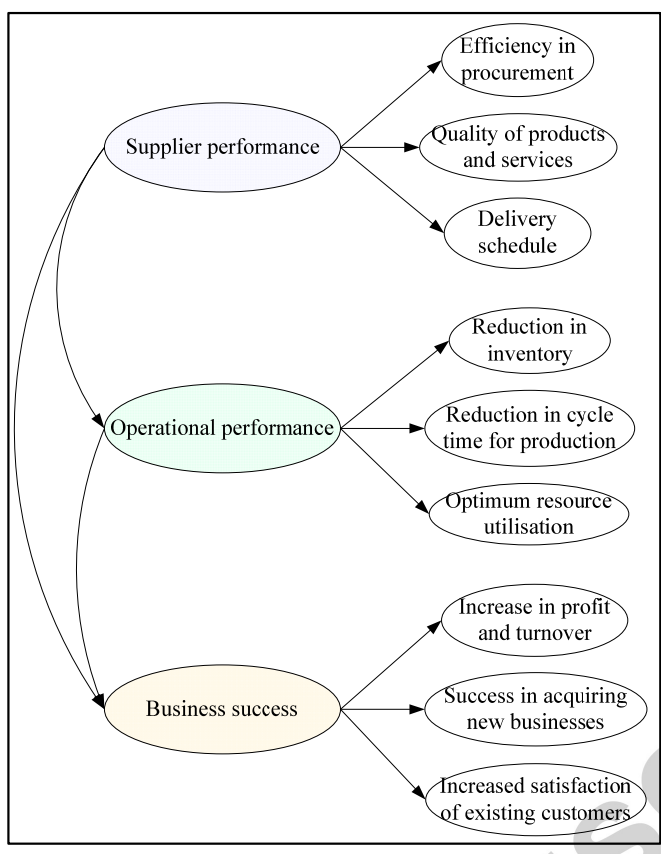

Figure 5: Causal relationship among the goals of the enterprise attributed to its activities 


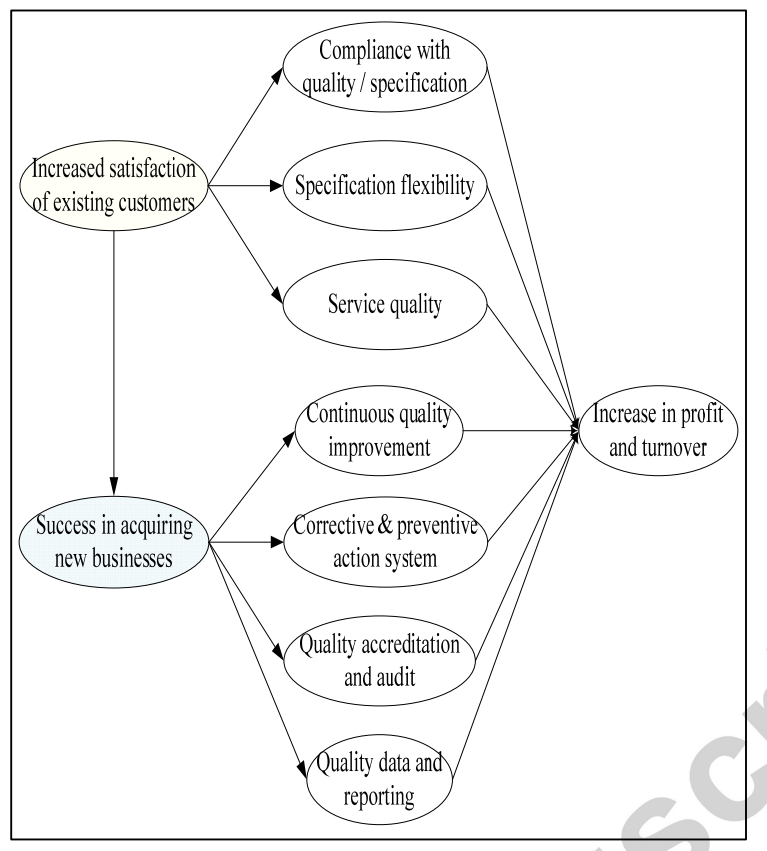

Figure 6: Causal relationship among the quality performance factors and business success attributes 


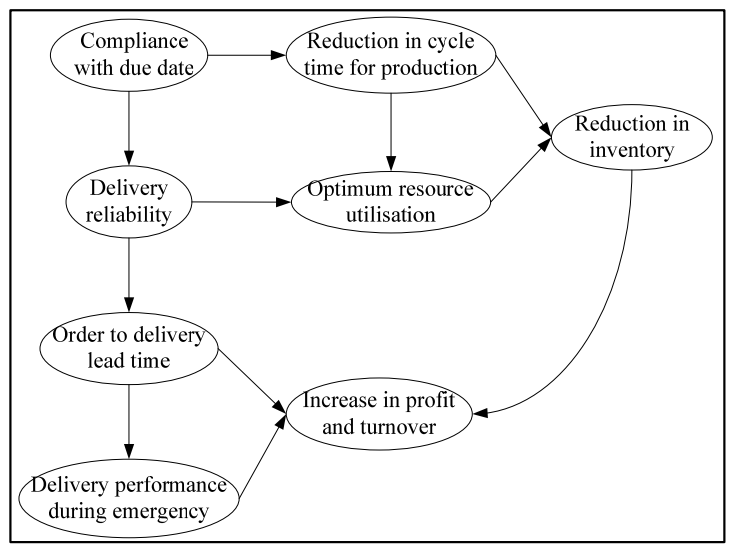

Figure 7: Causal relationship among the delivery performance factors and operational performance attributes 


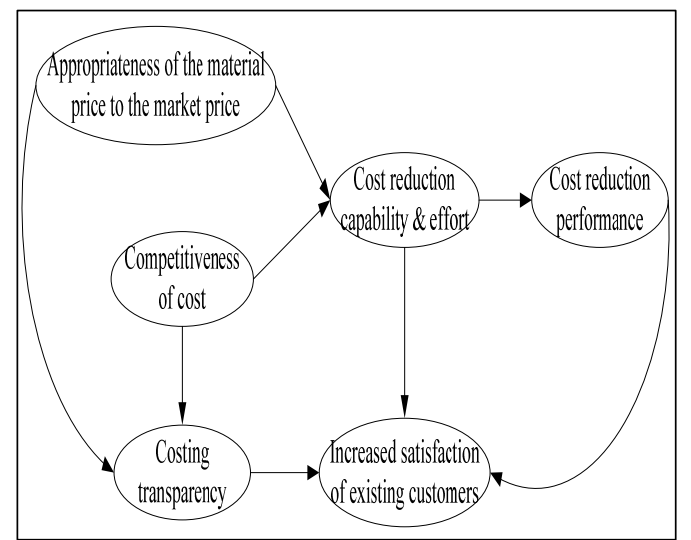

Figure 8: Causal relationship among the costing performance factors and business success attributes 


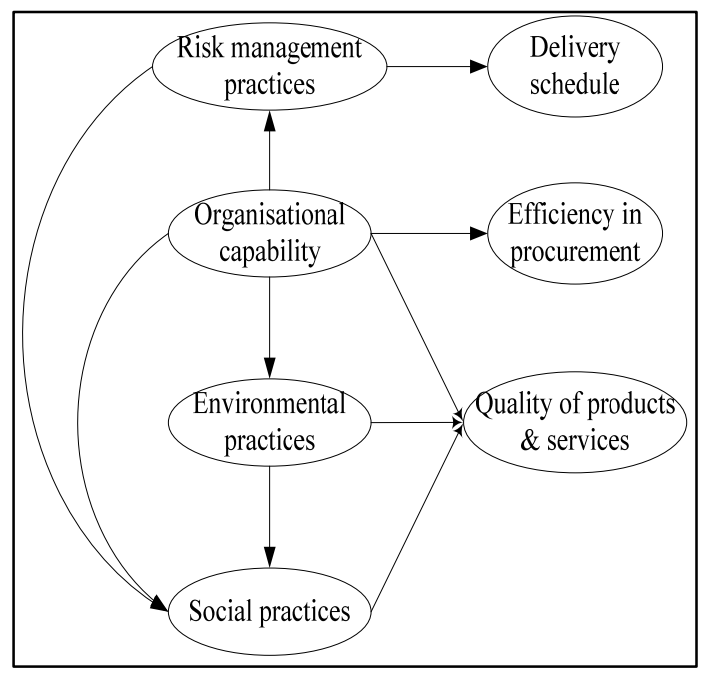

Figure 9: Causal relationship among the proactive factors and supplier performance attributes 


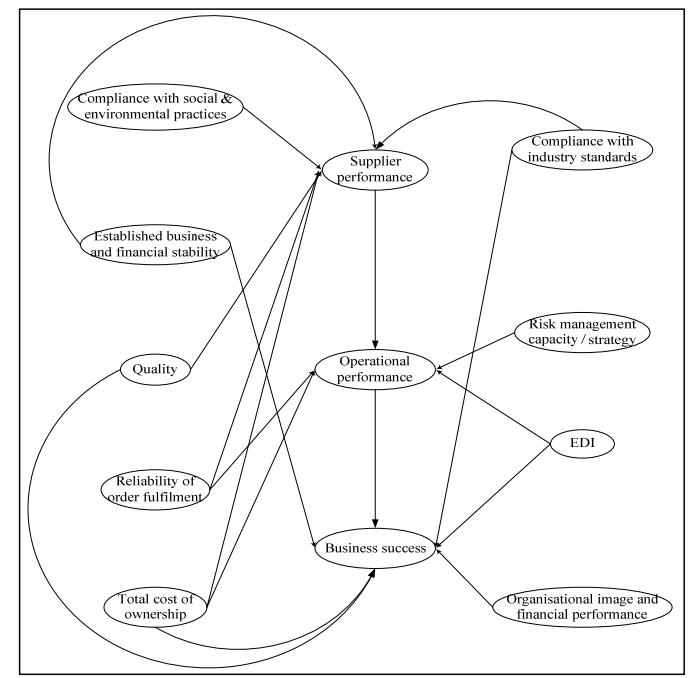

Figure 10: Causal relationship among the stakeholders' requirements and goals of the enterprise 


\section{Appendices}

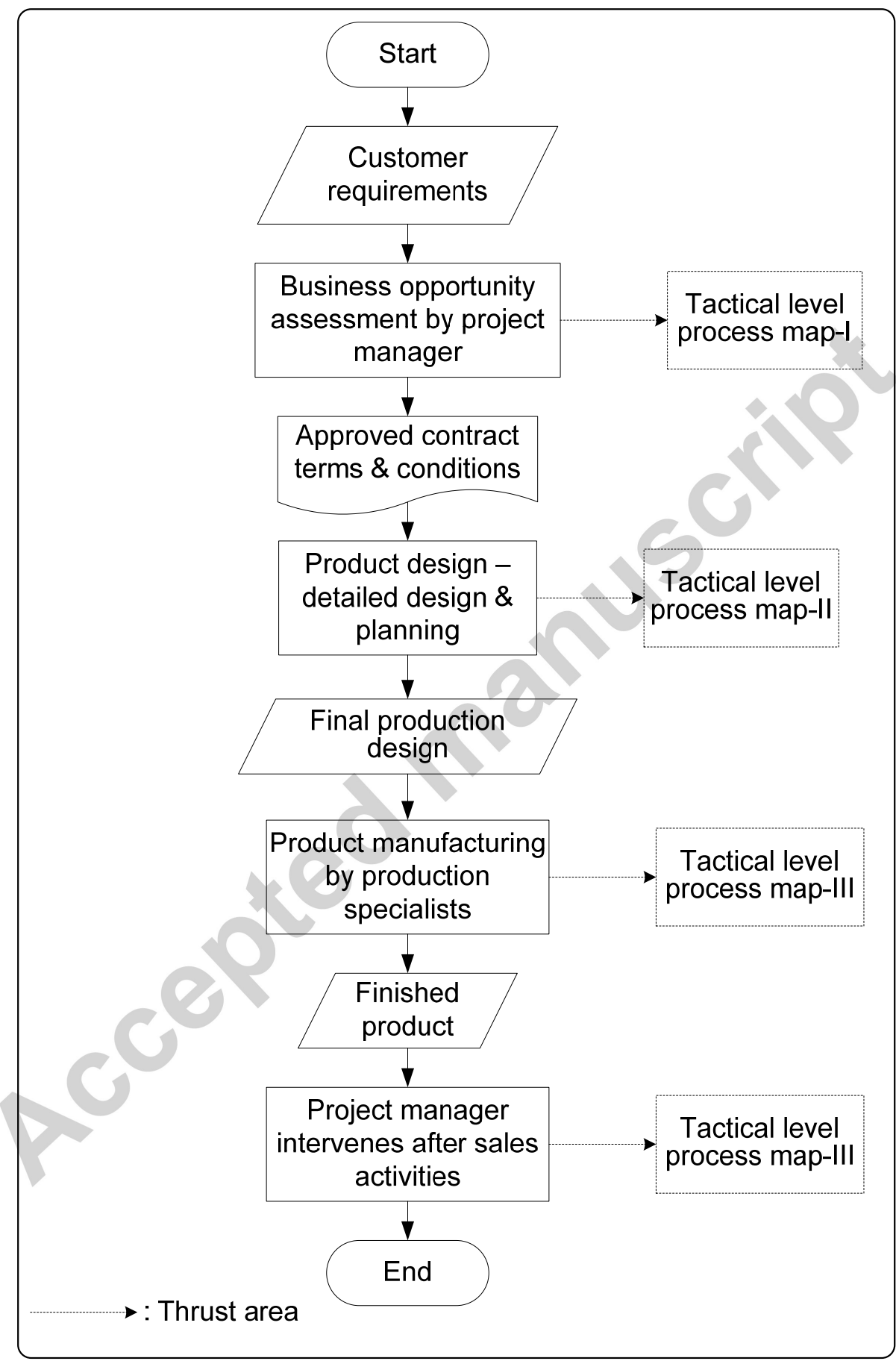

Figure A1: Strategic business processes of the case study organisation 


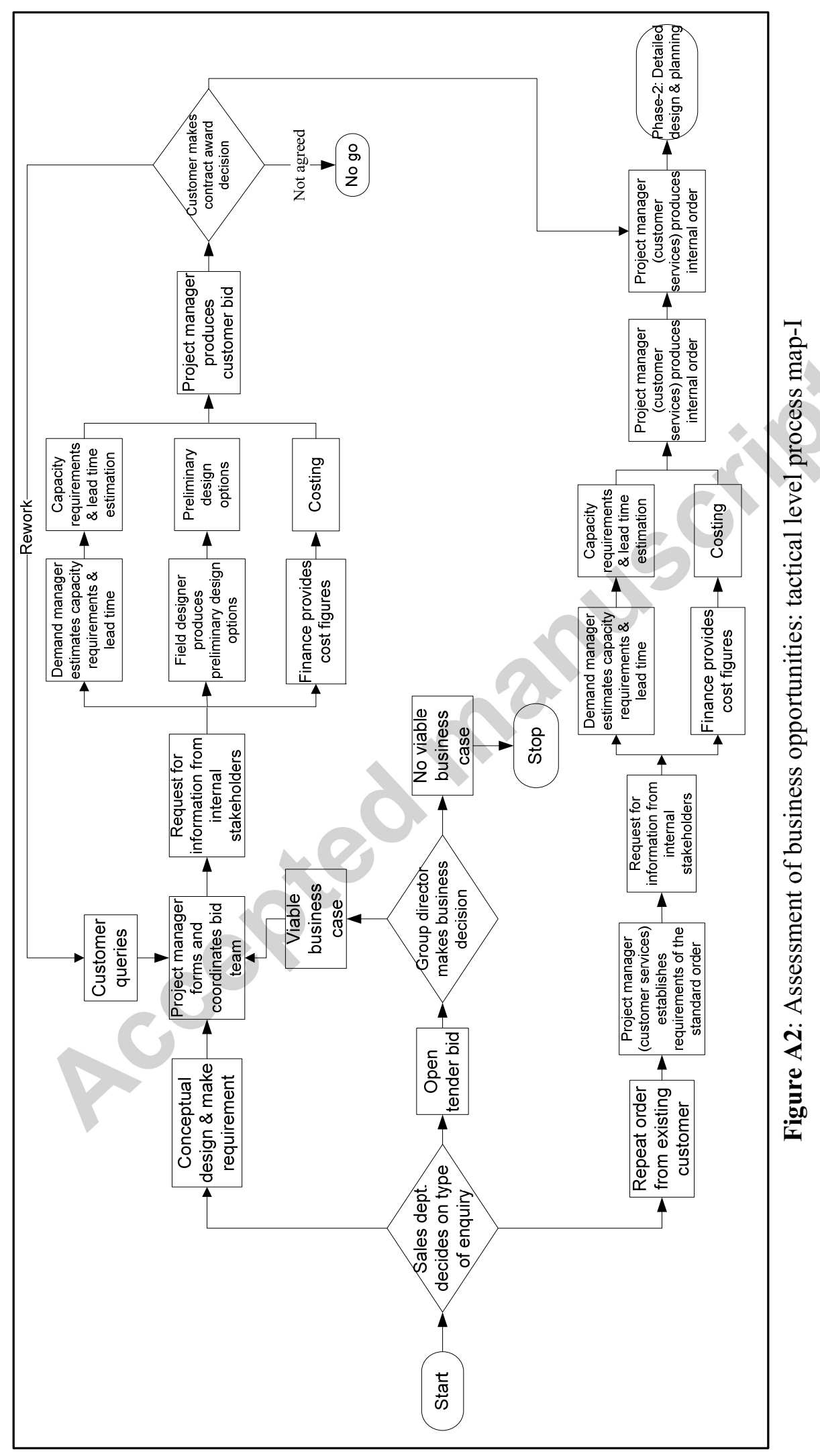




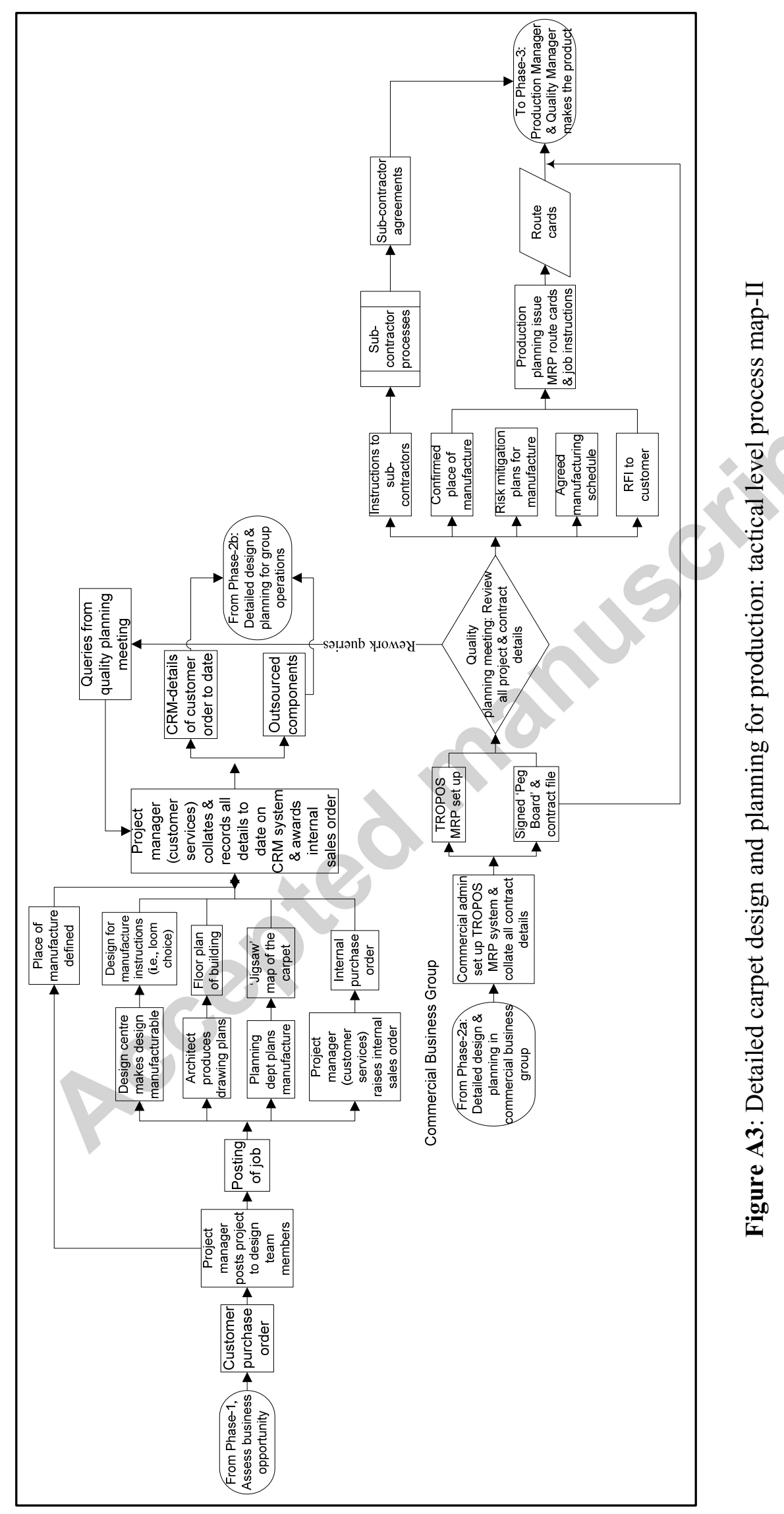




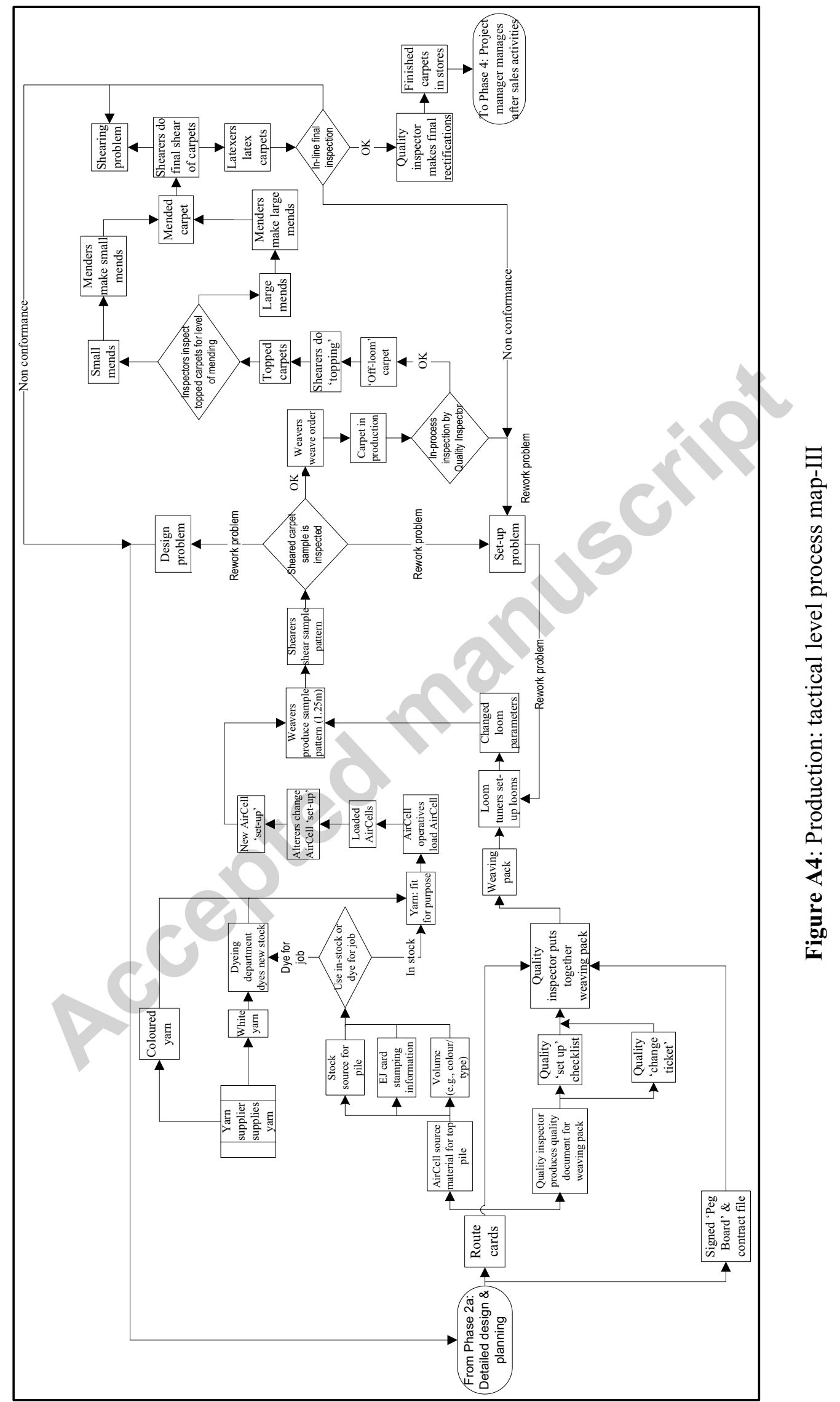


Table A1: Normalised matrix for stakeholders

\begin{tabular}{lcccccccc}
\hline & $\begin{array}{c}\text { Financial } \\
\text { department }\end{array}$ & $\begin{array}{c}\text { Procurement } \\
\text { Department }\end{array}$ & $\begin{array}{c}\text { Production } \\
\text { Department }\end{array}$ & $\begin{array}{c}\text { Quality } \\
\text { department }\end{array}$ & $\begin{array}{c}\text { Technical } \\
\text { department }\end{array}$ & $\begin{array}{c}\text { Marketing } \\
\text { department }\end{array}$ & $\begin{array}{c}\text { Top } \\
\text { Management }\end{array}$ & Importance \\
\hline $\begin{array}{l}\text { Financial } \\
\text { department }\end{array}$ & 0.0541 & 0.0449 & 0.0689 & 0.0577 & 0.03615 & 0.0364 & 0.0909 & 0.056 \\
$\begin{array}{l}\text { Procurement } \\
\text { Department }\end{array}$ & 0.1622 & 0.1348 & 0.1149 & 0.1154 & 0.2169 & 0.2182 & 0.1818 & 0.163 \\
$\begin{array}{l}\text { Production } \\
\text { Department }\end{array}$ & 0.2703 & 0.4045 & 0.3448 & 0.4615 & 0.2892 & 0.3273 & 0.2273 & 0.332 \\
$\begin{array}{l}\text { Quality department } \\
\text { Dechnical }\end{array}$ & 0.2162 & 0.2697 & 0.1149 & 0.2308 & 0.2169 & 0.2182 & 0.1818 & 0.207 \\
$\begin{array}{l}\text { department } \\
\text { Marketing }\end{array}$ & 0.1081 & 0.0449 & 0.1724 & 0.0769 & 0.0723 & 0.0545 & 0.1364 & 0.095 \\
department & 0.1622 & 0.0674 & 0.1149 & 0.1154 & 0.1446 & 0.1091 & 0.1364 & 0.121 \\
Top Management & 0.0270 & 0.0337 & 0.0689 & 0.05769 & 0.0241 & 0.0364 & 0.0455 & 0.025 \\
\hline
\end{tabular}


Table A2: Relative importance of stakeholders' requirements (provided by the organisation)

\begin{tabular}{|c|c|c|c|c|c|c|c|c|c|c|}
\hline 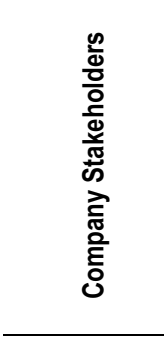 & 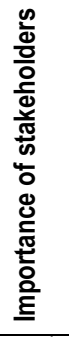 & 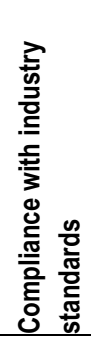 & 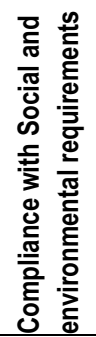 & 高 & 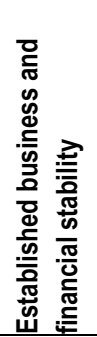 & $\frac{7}{\frac{7}{\pi}}$ & 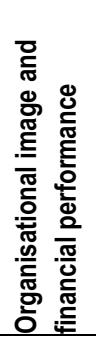 & 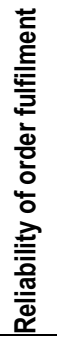 & 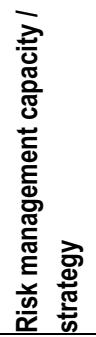 & 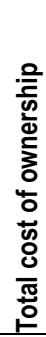 \\
\hline $\begin{array}{l}\text { Financial } \\
\text { department }\end{array}$ & $6^{\text {th }}$ & 2 & 0 & 3 & 9 & 7 & 9 & 7 & 7 & 9 \\
\hline $\begin{array}{l}\text { Procurement } \\
\text { Department }\end{array}$ & $3^{\text {rd }}$ & 0 & 5 & 3 & 7 & 7 & 3 & 5 & 5 & 5 \\
\hline $\begin{array}{l}\text { Production } \\
\text { Department }\end{array}$ & $1^{\text {st }}$ & 5 & 5 & 1 & 5 & 9 & 3 & 7 & 5 & 3 \\
\hline $\begin{array}{l}\text { Quality } \\
\text { department }\end{array}$ & $2^{\text {nd }}$ & 7 & 3 & 0 & 5 & 9 & 0 & 9 & 5 & 5 \\
\hline $\begin{array}{l}\text { Technical } \\
\text { department }\end{array}$ & $5^{\text {th }}$ & 5 & 3 & 0 & 3 & & 0 & 0 & 4 & 0 \\
\hline $\begin{array}{l}\text { Marketing } \\
\text { department }\end{array}$ & $4^{\text {th }}$ & 5 & 0 & 3 & & 9 & 9 & 9 & 5 & 0 \\
\hline $\begin{array}{l}\text { Top } \\
\text { Management }\end{array}$ & $7^{\text {th }}$ & 9 & 3 & 4 & 7 & 9 & 9 & 9 & 7 & 7 \\
\hline
\end{tabular}

(9 represents strong relationship and 0 represents no relationship) 


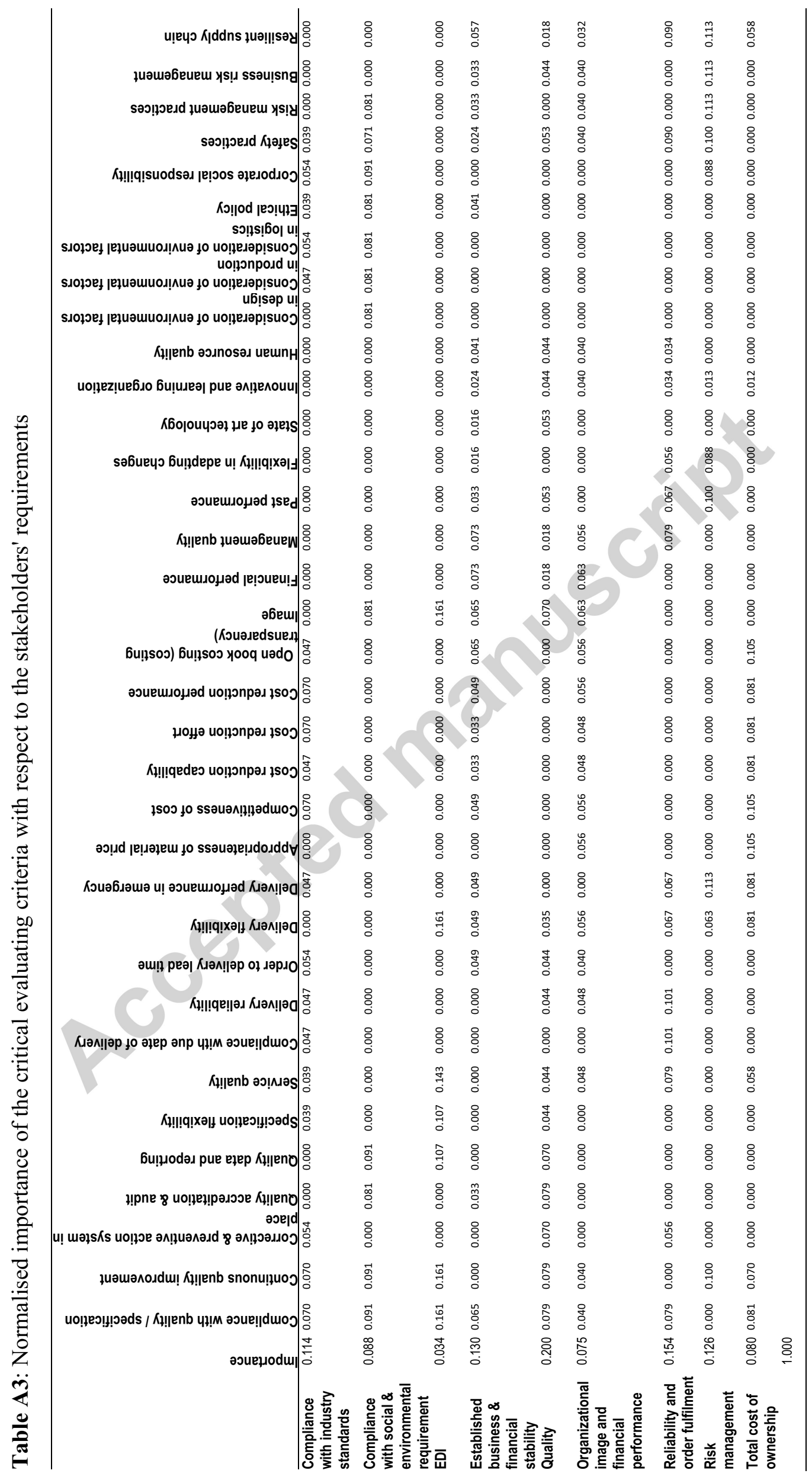




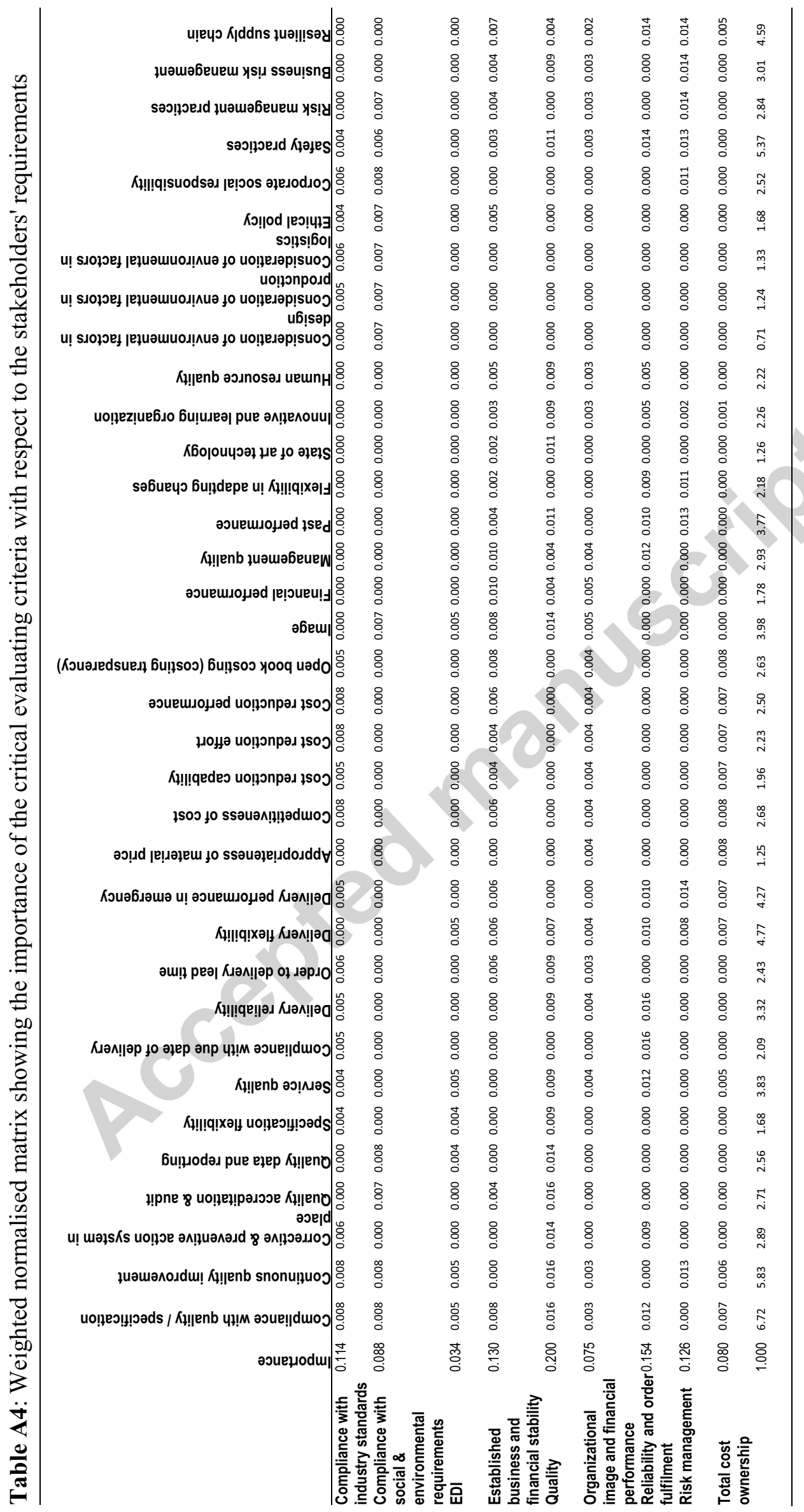




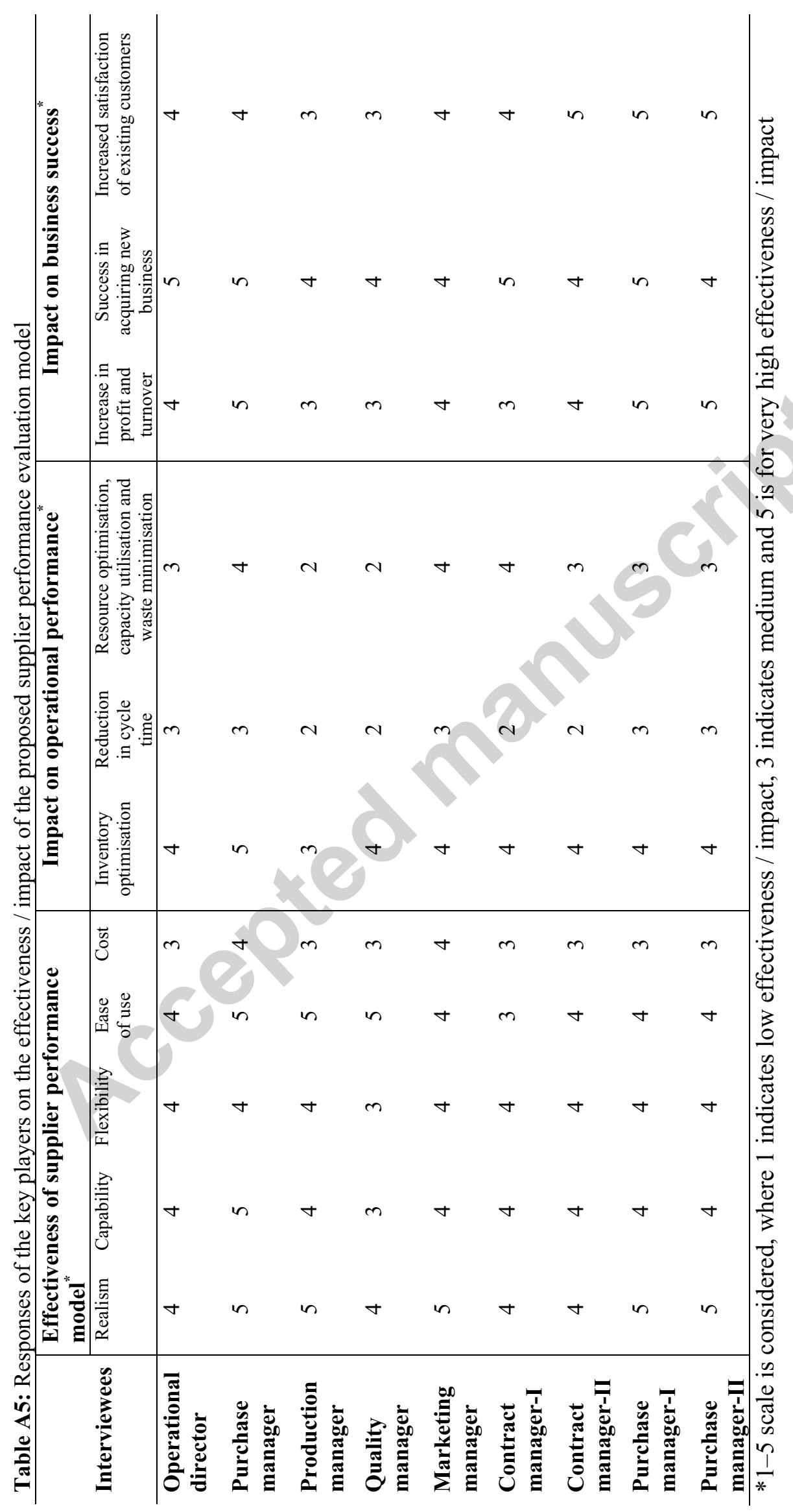


Table A6: List of the criteria with literature sources

\begin{tabular}{|c|c|}
\hline Criteria & Sources \\
\hline \multirow{9}{*}{ Quality performance } & Lehmann and O'Shaughnessy, (1982) \\
\hline & Wilson (1984) \\
\hline & Swift (1995) \\
\hline & Goffin et al. (1997) \\
\hline & Narasimhan et al. (2001) \\
\hline & Quayle (2002) \\
\hline & Chan et al. (2008) \\
\hline & Sen et al. (2008) \\
\hline & Kuo and Lin (2011) \\
\hline \multirow{6}{*}{ Delivery performance } & Lehmann and O'Shaughnessy, (1982) \\
\hline & Goffin et al. (1997) \\
\hline & Quayle (2002) \\
\hline & Chan et al. (2008) \\
\hline & Sen et al. (2008) \\
\hline & Kuo and Lin (2011) \\
\hline \multirow{5}{*}{ Costing performance } & Swift (1995) \\
\hline & Goffin et al. (1997) \\
\hline & Chan et al. (2008) \\
\hline & Sen et al. (2008) \\
\hline & Quayle (2002) \\
\hline \multirow{5}{*}{$\begin{array}{l}\text { Organisational } \\
\text { capability }\end{array}$} & Schmitz and Platts (2004) \\
\hline & Quayle (2002) \\
\hline & Chan et al. (2008) \\
\hline & Sen et al. (2008) \\
\hline & Narasimhan et al. (2001) \\
\hline \multirow{3}{*}{$\begin{array}{l}\text { Environmental } \\
\text { practices }\end{array}$} & Schmitz and Platts (2004) \\
\hline & Kuo and Lin (2011) \\
\hline & Chan et al. (2008) \\
\hline \multirow{3}{*}{ Social practices } & Schmitz and Platts (2004) \\
\hline & Kuo and Lin (2011) \\
\hline & Chan et al. (2008) \\
\hline \multirow{2}{*}{$\begin{array}{l}\text { Risk management } \\
\text { practices }\end{array}$} & Schmitz and Platts (2004) \\
\hline & Kuo and Lin (2011) \\
\hline
\end{tabular}

